\title{
Plexin-B2 Regulates the Proliferation and Migration of Neuroblasts in the Postnatal and Adult Subventricular Zone
}

\author{
Bhaskar Saha, ${ }^{1,2,3}$ Athéna R. Ypsilanti, ${ }^{1,2,3}$ Camille Boutin, ${ }^{4}$ Harold Cremer, ${ }^{4}$ and Alain Chédotal ${ }^{1,2,3}$ \\ ${ }^{1}$ Institut National de la Santé et de la Recherche Médicale, UMR S968, ${ }^{2}$ Université Pierre et Marie Curie Paris VI, UMR S968, and ${ }^{3}$ CNRS UMR 7210, Institut \\ de la Vision, F-75012 Paris, France, and 4Institut de Biologie du Développement de Marseille Luminy, UMR 6216, CNRS/Université de la Méditerrannée, \\ Campus de Luminy, F-13288 Marseille, France
}

In the postnatal forebrain, the subventricular zone (SVZ) contains a pool of undifferentiated cells, which proliferate and migrate along the rostral migratory stream (RMS) to the olfactory bulb and differentiate into granule cells and periglomerular cells. Plexin-B2 is a semaphorin receptor previously known to act on neuronal proliferation in the embryonic brain and neuronal migration in the cerebellum. We show here that, in the postnatal and adult CNS, Plexin-B2 is expressed in the subventricular zone lining the telencephalic ventricles and in the rostral migratory stream. We analyzed $P l x n b 2^{-1-}$ mice and found that there is a marked reduction in the proliferation of SVZ cells in the mutant. Plexin-B2 expression is downregulated in the olfactory bulb as interneurons initiate radial migration. BrdU labeling and GFP electroporation into postnatal SVZ, in addition to time-lapse videomicroscopy, revealed that neuroblasts deficient for Plexin-B2 migrate faster than control ones and leave the RMS more rapidly. Overall, these results show that Plexin-B2 plays a role in postnatal neurogenesis and in the migration of SVZ-derived neuroblasts.

\section{Introduction}

In the olfactory bulb (OB) of mammals, granule cells (GCs) and periglomerular cells (PGs) originate in the subventricular zone (SVZ) lining the lateral wall of the cerebral ventricles and their precursors migrate along the rostral migratory stream (RMS) to the OB (Lois and Alvarez-Buylla, 1994; Sanai et al., 2011). Most PG and GC neurons are generated after birth and are continuously produced over life (Luskin, 1993; Luskin et al., 1993). In the RMS, neuroblasts become ensheathed during the postnatal period by astrocytes and migrate tangentially along one another forming so-called chains (Jankovski and Sotelo, 1996; Lois et al., 1996). Upon entering the OB, cells switch to a radial mode of migration perpendicular to the $\mathrm{OB}$ surface, possibly following blood vessels (Bovetti et al., 2007; Snapyan et al., 2009) before integrating into the existing circuitry (Carleton et al., 2003; Ghashghaei et al., 2007; Kelsch et al., 2008).

Several studies indicate that axon guidance molecules of the Slit (Hu, 1999; Wu et al., 1999; Nguyen-Ba-Charvet et al., 2004; Sawamoto et al., 2006; Kaneko et al., 2010), ephrin

Received Jan. 23, 2012; revised Sept. 10, 2012; accepted Sept. 26, 2012.

Author contributions: A.C. designed research; B.S., A.R.Y., C.B., and H.C. performed research; C.B. and H.C. contributed unpublished reagents/analytic tools; B.S., A.R.Y., and A.C. analyzed data; B.S., A.R.Y., and A.C. wrote the paper.

This work was supported by a grant from the Fondation pour la Recherche Médicale (FRM) (Programme Équipe) (A.C.). B.S. was a recipient of a postdoctoral fellowship from the Fyssen Foundation and the Neuropole Région Île-de-France. A.R.Y. was supported by fellowships from the Natural Sciences and Engineering Research Council of Canada, the FRM, and the Paris School of Neurosciences. We thank Dr. M. Okabe (Osaka University, Osaka, Japan) for the pCX::GFP plasmid, M. Tessier-Lavigne (Rockefeller University, New York, NY) for providing the Plxnb2 knock-out, and S. Fouquet (Imaging Facility of the Vision Institute) for help with quantification and image acquisition.

Correspondence should be addressed to Alain Chédotal, Institut de la Vision, 17 Rue Moreau, F-75012 Paris, France. E-mail: alain.chedotal@inserm.fr.

DOI:10.1523/JNEUROSCI.0344-12.2012

Copyright $\odot 2012$ the authors $\quad 0270-6474 / 12 / 3216892-14 \$ 15.00 / 0$
(Conover et al., 2000; Holmberg et al., 2005; Jiao et al., 2008), and netrin (Hakanen et al., 2011) families might control the production and migration of SVZ-derived cells in the postnatal forebrain (Ghashghaei et al., 2007). Surprisingly, the function of semaphorins in postnatal neurogenesis and migration has not yet been studied. Semaphorins are axon guidance molecules that control neuronal migration in the developing nervous system (Chen et al., 1997; Marín and Rubenstein, 2001; Kerjan et al., 2005; Tran et al., 2007; Giacobini et al., 2008; Ito et al., 2008; Renaud et al., 2008). Plexins are receptors of membrane-bound semaphorins, and of the secreted semaphorin Sema3E (Tamagnone et al., 1999; Gu et al., 2005; Pasterkamp and Giger, 2009). Plexins are subdivided into four subgroups (A-D) based on structural features (Takeuchi et al., 2005). Type B plexins (B1, B2, and B3) are receptors for class IV and possibly class V transmembrane semaphorins (Artigiani et al., 2004; Oinuma et al., 2004; Deng et al., 2007; Yukawa et al., 2010a; Maier et al., 2011; Perälä et al., 2011). Type B plexins are expressed in the postnatal CNS where their function is largely unknown (Worzfeld et al., 2004; Friedel et al., 2007). The analysis of the CNS of the Plxnb1 and Plxnb3 single knock-outs failed to reveal any defects suggesting that type B Plexins may act redundantly (Deng et al., 2007; Worzfeld et al., 2009). By contrast, Plxnb2 knock-out mice display neural tube defects and disorganization of the cerebellar cortex (Deng et al., 2007; Friedel et al., 2007; Maier et al., 2011; Wansleeben et al., 2011). Whether or not Plexin-B2 plays a role in postnatal neurogenesis in the telencephalon has not yet been determined.

We show here that Plexin-B2 is expressed by SVZ neuroblasts and most of their progeny in the postnatal and adult mouse brain. The analysis of $P l x n b 2^{-1-}$ mice demonstrates an important role for Plexin-B2 in postnatal and adult neurogenesis. 


\section{Materials and Methods}

Animals. The Plxnb2 gene was mutated by targeted trapping as described previously (Friedel et al., 2007). Heterozygote mice Plxnb2 ${ }^{+/-}$females maintained in CD1 background were crossed to heterozygous Plxnb2 ${ }^{+1-}$ males in the same background to obtain $P l x n b 2^{-1-}$ mice. The day of birth was considered as postnatal day $0(\mathrm{P} 0)$. Postnatal pups were anesthetized on ice and either pentobarbital ( $\sim 150 \mu$ l per pup) or a mixture of ketamine $(100 \mathrm{mg} / \mathrm{ml})$ and xylazine $(10 \mathrm{mg} / \mathrm{ml})$ was used to anesthetize adult mice of either sex. Plxnb2 characterization was performed on CD1 wild-type mice of either sex of the appropriate ages. All animal procedures were performed in accordance with institutional guidelines (Université Pierre et Marie Curie and Institut National de la Santé et de la Recherche Médicale).

Immunohistochemistry. Mice were perfused using 4\% paraformaldehyde in $0.1 \mathrm{~m}$ phosphate buffer, $\mathrm{pH} 7.4$, and cryoprotected in $10 \%$ sucrose (in $0.1 \mathrm{~m}$ phosphate buffer) for cryostat sectioning or $30 \%$ sucrose for freezing microtome sectioning. Cryostat sections (20 $\mu \mathrm{m}$ thick) and microtome sections ( $40 \mu \mathrm{m}$ thick) were blocked in PBS containing $0.2 \%$ gelatin and $0.25 \%$ Triton $\mathrm{X}-100$ and incubated overnight at room temperature with primary antibodies against polysialated neural cell adhesion molecule (PSA-NCAM) (1:10,000; mouse IgM ascites; Abcys), Doublecortin (1:1000, goat, Santa Cruz; or 1:300, rabbit, Cell Signaling), Plexin-B2 (1:100; Armenian hamster; eBioscience), GFAP (1:400; mouse IgG1; Millipore Bioscience Research Reagents), $\beta$-gal (1:1000; rabbit; Cappel), GABA (1:1000; rabbit; Sigma-Aldrich), tyrosine hydroxylase (TH) (1:2000; mouse monoclonal; Diasorin), Pax6 (1:1000; rabbit; Millipore Bioscience Research Reagents), calretinin (1:1000; goat; Swant), green fluorescent protein (GFP) (1:800, chicken, Abcam; and 1:1000, rabbit, Life Technologies), followed by species-specific antibodies conjugated with fluorophores (Jackson ImmunoResearch). Sections counterstained with Hoechst $33258(10 \mu \mathrm{g} / \mathrm{ml}$; Sigma-Aldrich $)$ were examined with a fluorescent microscope (DM6000; Leica) coupled to a CoolSnapHQ camera (Roper Scientific) or a confocal microscope (FV1000; Olympus).

In situ hybridization. Antisense riboprobes were labeled with DIG (digoxigenin-11-UTP, Roche) as described previously (Marillat et al., 2002) by in vitro transcription of cDNA encoding Plxnb2 (Friedel et al., 2007) or class IV semaphorins (Friedel et al., 2007). cDNAs were linearized followed by transcription reaction using Sp6 or T7 RNA polymerase (Roche). In situ hybridization was performed as described previously (Marillat et al., 2002).

Olfactory bulb volume measurement. For olfactory bulb volume, the area of the OB sections (one in five sections) was measured using MetaMorph software. The mean area was multiplied by section thickness and number of sections (area by thickness by number of sections) to get the volume of the $\mathrm{OB}$.

BrdU labeling and quantification. Bromodeoxyuridine (BrdU) (SigmaAldrich; $50 \mathrm{mg} / \mathrm{kg}$ body weight, diluted in physiological saline $0.9 \%$ $\mathrm{NaCl}, 0.007 \mathrm{~N} \mathrm{NaOH}$ to a concentration of $15 \mathrm{mg} / \mathrm{ml}$ ) was injected intraperitoneally in adult $P l x n b 2^{+1-}$ and Plxnb2 $2^{-1-}$ mice. Mice were perfused with $4 \%$ paraformaldehyde after $3 \mathrm{~h}, 4 \mathrm{~d}$, and $30 \mathrm{~d}$. Brains were cryosectioned $(20 \mu \mathrm{m})$ and sections were incubated in $2 \mathrm{~N} \mathrm{HCl}$ in PBS for $30 \mathrm{~min}$ at $37^{\circ} \mathrm{C}$. Immunohistochemistry was performed using an antiBrdU antibody (1:100; Harlan). To quantify the number of BrdUpositive cells, images were acquired using a Leica DM6000 microscope ( $20 \times$ objective). Counting was performed using MetaMorph software. Four different rostrocaudal levels were selected (see Fig. 5), and 10 serial sections were counted at each level. Statistical significance was calculated using an unpaired two-tailed $t$ test. Compiled data were expressed as SEM.

Electroporation. Electroporation of postnatal pups (P2-P3) was performed as previously described (Boutin et al., 2008) with minor modifications. Briefly, pups were anesthetized by hypothermia. A small hole was pierced into their skull using a surgical suturing needle (Ethicon; Perma-Hand; 3-0; Johnson \& Johnson) at the level of the lateral ventricles. Approximately $2 \mu \mathrm{l}$ of endotoxin-free pCX-EGFP (500 ng/ $\mu \mathrm{l}$; kind gift from Dr. M. Okabe, Osaka University, Osaka, Japan) was injected into the right lateral ventricle using a pulled glass capillary. By placing electrodes (CUY650P3; Sonidel) coated with a conductance gel on the head of the pups, electric pulses were applied immediately after DNA delivery (five pulses, $100 \mathrm{~V}, 50 \mathrm{~ms}$ pulse length, $850 \mathrm{~ms}$ intervals between two pulses) using a CUY21EDIT electroporator (Nepagene). Pups were then placed at $37^{\circ} \mathrm{C}$ for warming before being returned to their mother. Electroporated pups were perfused after $5 \mathrm{~d}$ (to assess migration) and $20 \mathrm{~d}$ (to assess differentiation). Using a sliding freezing microtome, 70 $\mu \mathrm{m}$ sagittal sections were cut from the frontal part (includes $\mathrm{OB}$ and the RMS) of the electroporated hemisphere and processed for GFP immunostaining in floating condition. The rest of the brain was cut coronally $(35 \mu \mathrm{m})$ and processed similarly to check septal migration of neuroblasts in the mutant.

Live cell imaging. P2-P3 pups were electroporated as described above. Five days following electroporation, sagittal slices (300 $\mu \mathrm{m}$ thick) of the elecroporated hemispheres were prepared in ice-cold Gey's balanced salt solution (Sigma-Aldrich) supplemented with 1\% (v/v) glucose solution (Sigma-Aldrich) using a vibratome (Leica VT 1000S). Slices containing GFP + cells in the RMS were chosen for live imaging and were placed on a Millicell filter (Millipore) in a $60 \mathrm{~mm}$ dish containing $1 \mathrm{ml}$ of medium: BME supplemented with glucose, L-glutamine BSA fraction, ITS supplement, and penicillin-streptomycin. The slices were subsequently covered with a thin layer of rat tail collagen and placed in a $\mathrm{CO}_{2}$ incubator for $1 \mathrm{~h}$ before imaging. Slices were place in medium, and images were taken with a Leica DM6000 microscope using a $20 \times$ immersion objective. Acquisitions were performed every 4 min using the MetaMorph software. ImageJ software was used to process the images.

For calculation of migration speed, only cells having migrated unidirectionally for $>1 \mathrm{~h}$ were considered. Migration distances were calculated by Manual Tracking using ImageJ, and corresponding speeds were measured by dividing the distance by the time of migration. A two-tailed unpaired $t$ test was performed to calculate the statistical difference of the migration speed between Plxnb2 $2^{+1-}$ and Plxnb2 ${ }^{-1-}$ groups.

Explant culture. Brains from P4 or P5 pups (both Plxnb2 $2^{+/-}$and Plxnb2 ${ }^{-1-}$ ) were dissected out and $250 \mu \mathrm{m}$ coronal slices were cut in ice-cold PBS supplemented with $1 \%(\mathrm{v} / \mathrm{v})$ glucose solution (SigmaAldrich) using a vibratome (Leica VT 1000S). RMS explants were dissected in PBS/glucose with 5\% FBS (PAA) from slices containing anterior part of the RMS. Explants were embedded in Matrigel (BD Biosciences) on $12 \mathrm{~mm}$ coverslips, and cultured for $36 \mathrm{~h}$ in Neurobasal medium supplemented with B27, L-glutamine, and Pen-Strep (all from Life Technologies). To analyze the effect of growth factors, either glial cell linederived neurotrophic factor (GDNF) (200 ng/ml; R\&D Systems) or hepatocyte growth factor (HGF) (50 ng/ml; Sigma-Aldrich) were added in the culture media. For GDNF and HGF, several concentrations were tested with WT explants $(50,100$, and $200 \mathrm{ng} / \mathrm{ml})$. A concentration of 50 $\mathrm{ng} / \mathrm{ml}$ was chosen for HGF, and $200 \mathrm{ng} / \mathrm{ml}$ for GDNF (see Results). Control explants did not contain any growth factor. Thereafter, the explants were fixed in 4\% PFA and stained for nuclear marker To-Pro-3iodide (Life Technologies). Confocal images were acquired and overlaid stacks were used for counting cell numbers.

Quantification of cell migration was performed using ImageJ and IMARIS software. The number of cell nuclei within each area was counted using IMARIS software ( 10 pixel $=1$ nucleus at $20 \times$ magnification). Compiled data was expressed as SEM, and statistical significance was calculated using Student's $t$ test.

\section{Results}

Plexin-B2 is expressed in the postnatal SVZ-RMS-OB system Plxnb2 mRNA has previously been shown to be expressed in the ventricular zone of the embryonic cortex and early postnatal RMS/SVZ (Deng et al., 2007; Hirschberg et al., 2010). To determine whether Plexin-B2 could play a role in postnatal neurogenesis, we first studied its expression pattern using in situ hybridization, immunostaining, and transgenic mice.

We found that, in the postnatal and in the adult mouse telencephalon, plxnb2 mRNA was highly expressed in the SVZ, throughout the RMS, and in the OB (Fig. 1A-C) (data not shown). In the OB, low levels of plxnb2 mRNA were also detected in the periglomerular cell layer (Fig. 1A). In the Plxnb2 knock- 

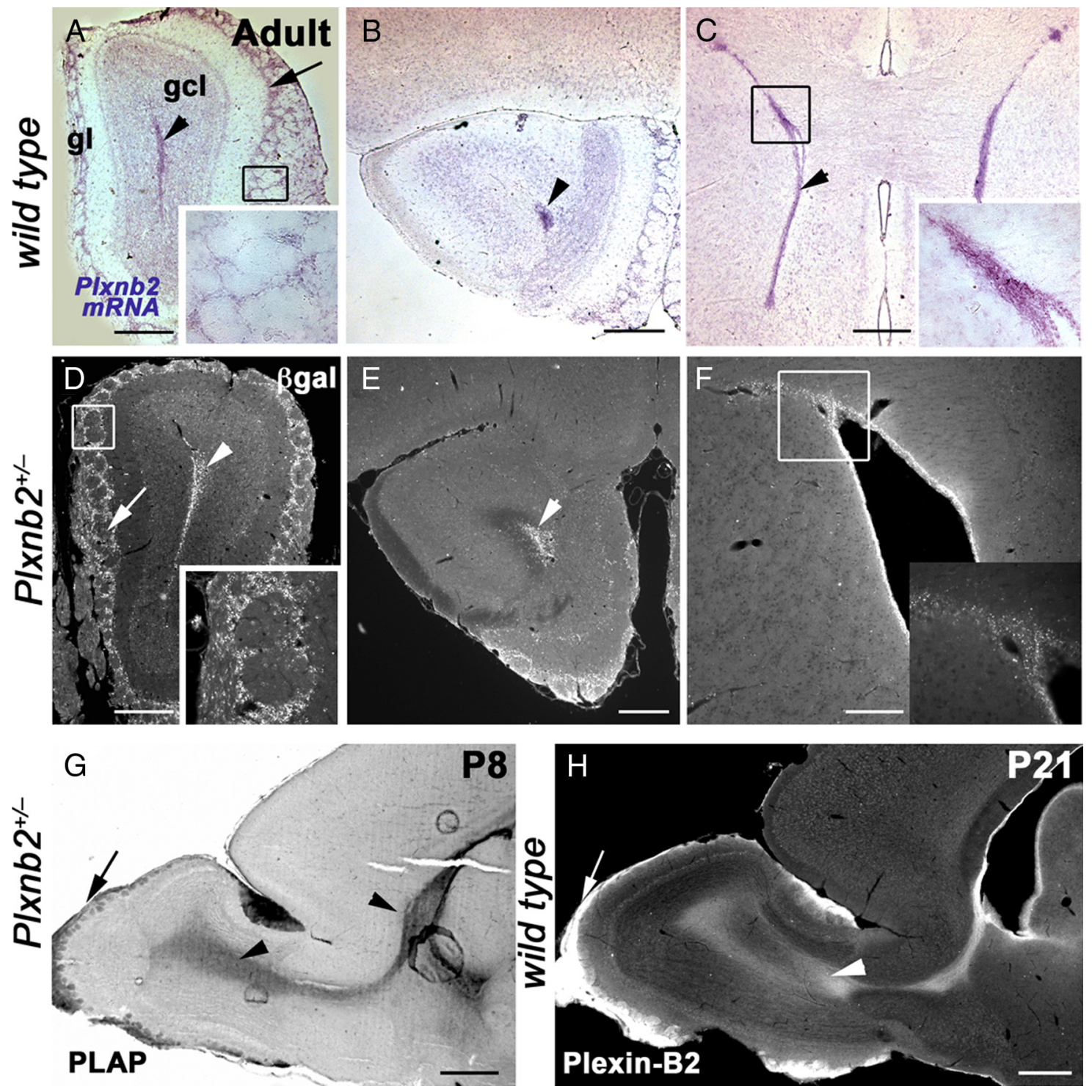

Figure 1. Plexin-B2 is expressed in the postnatal and adult SVZ-RMS. Sections $\boldsymbol{A}-\boldsymbol{F}$ are coronal. $\boldsymbol{A}-\boldsymbol{C}$, In the adult, in situ hybridization with Plxnb2 riboprobe showed that $P / x n b 2$ is highly expressed in the RMS $(\boldsymbol{A}, \boldsymbol{B}$, arrowhead), in the glomerular layer ( $(\mathbf{l})(\boldsymbol{A}$, arrows), and in the subventricular zone ( $\boldsymbol{C}$, arrowhead). The insets in $\boldsymbol{A}$ and $\boldsymbol{C}$ are high magnification of the boxed area. $\boldsymbol{D}-\boldsymbol{F}$, $\beta$-Galactosidase immunohistochemistry also revealed similar expression patterns in all three regions (insets are high magnification of the boxed areas). G, Sagittal section of the telencephalon of P8 Plxnb2 ${ }^{+/-}$mouse labeled for PLAP. PLAP is highly expressed in the RMS (arrowhead) and some olfactory axons (arrow). $\boldsymbol{H}$, Sagittal section of the telencephalon in a P21 mouse immunolabeled with anti-Plexin-B2 antibodies. Plexin-B2 is highly expressed in the RMS (arrowhead) and some olfactory axons (arrow). Scale bars: $\boldsymbol{A}-\boldsymbol{E}, 600 \mu \mathrm{m} ; \boldsymbol{F}, 200 \mu \mathrm{m} ; \boldsymbol{G}, 500 \mu \mathrm{m} ; \boldsymbol{H}, 600 \mu \mathrm{m}$.

out line, a cDNA cassette encoding $\beta$-galactosidase and placental alkaline phosphatase (PLAP) sequence was inserted by homologous recombination into intron 16 (Friedel et al., 2007). The expression pattern of these two reporters was previously shown to faithfully reproduce the endogenous expression of Plexin-B2 (Friedel et al., 2007). Accordingly, in postnatal and adult $P l x n b 2^{+1-}$ mice, both $\beta$-gal and PLAP were highly expressed in the SVZ, and all along the RMS to the OB (Fig. $1 D-G$ ) (data not shown). PLAP was also detected in olfactory glomeruli (Fig. $1 G$ ). In the adult $\mathrm{OB}, \beta$-gal was strongly expressed by periglomerular cells (Fig. $1 D$ ), weakly in mitral cells, but was not detectable in differentiated granule cells (Fig. $1 D, E$ ). Using a specific antiPlexin-B2 monoclonal antibody (Friedel et al., 2007), we confirmed that Plexin-B2 was highly expressed in the postnatal and adult SVZ and RMS (Figs. $1 H, 2$ ).

As was previously established, Plexin-B2 was highly expressed in the RMS during the first postnatal week (Fig. $2 A$ ). Interest- ingly, in the $\mathrm{OB}$, Plexin-B2 expression appeared to be rapidly downregulated outside of the RMS. To confirm this observation, P2 wild-type mice $(n=3)$ were electroporated with a plasmid encoding the GFP as previously described (Boutin et al., 2008). Electroporated animals were perfused $5 \mathrm{~d}$ after electroporation (P7). This showed that GFP-expressing cells with the typical unipolar morphology of migrating SVZ neuroblasts (Nam et al., 2007; Boutin et al., 2008) expressed Plexin-B2 in the RMS (Fig. $2 B-D)$. However, in the OB, Plexin-B2 was not expressed by radially migrating cells (Fig. $2 D$ ), suggesting that a downregulation of Plexin-B2 expression could accompany the initiation of radial migration. In adult mice, Plexin-B2 immunoreactivity was still detected in the RMS as well as PG cells. It also appeared to be weakly expressed by mitral cells and olfactory axons (Fig. 2E,F) (data not shown).

In the olfactory bulb, different classes of periglomerular cells were characterized based on their neurotransmitter content 


\section{P7 electroporated at P2}

A
RMS
GCL
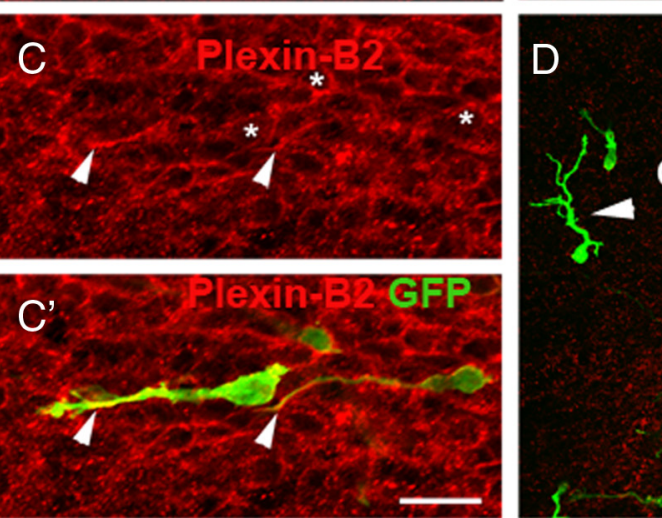
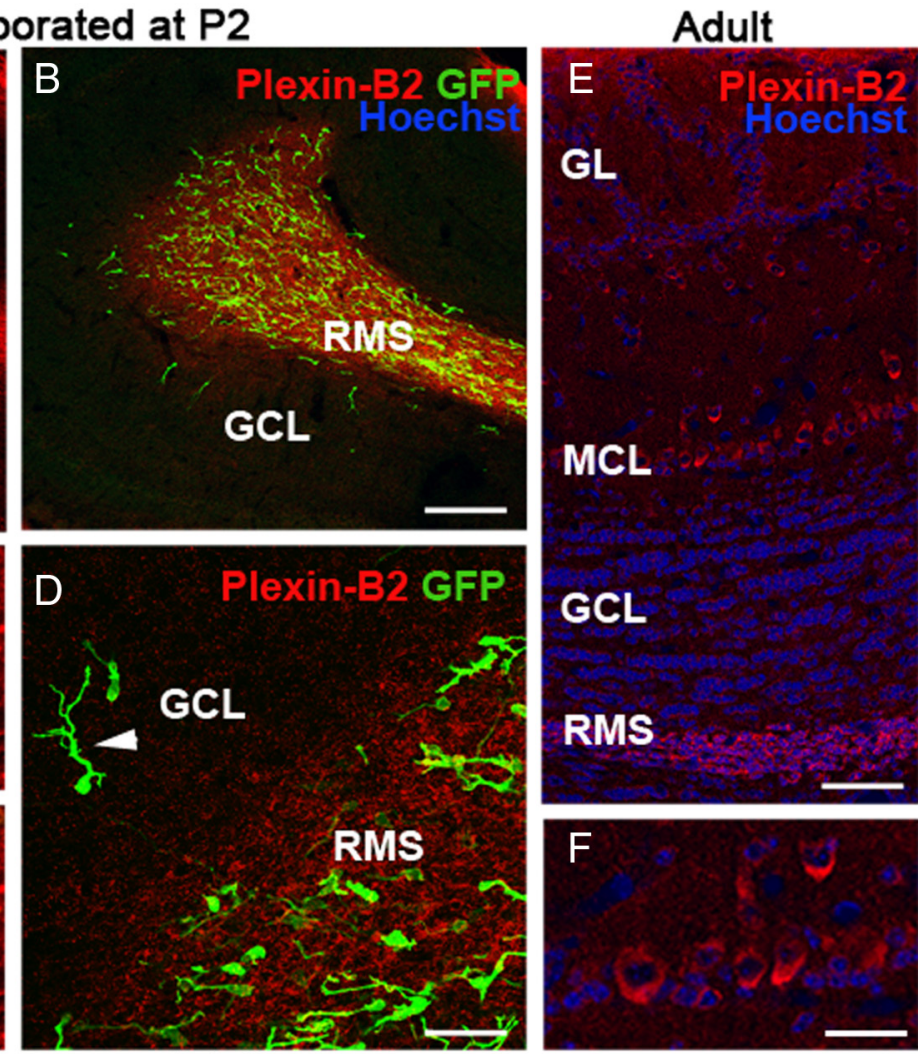

Adult
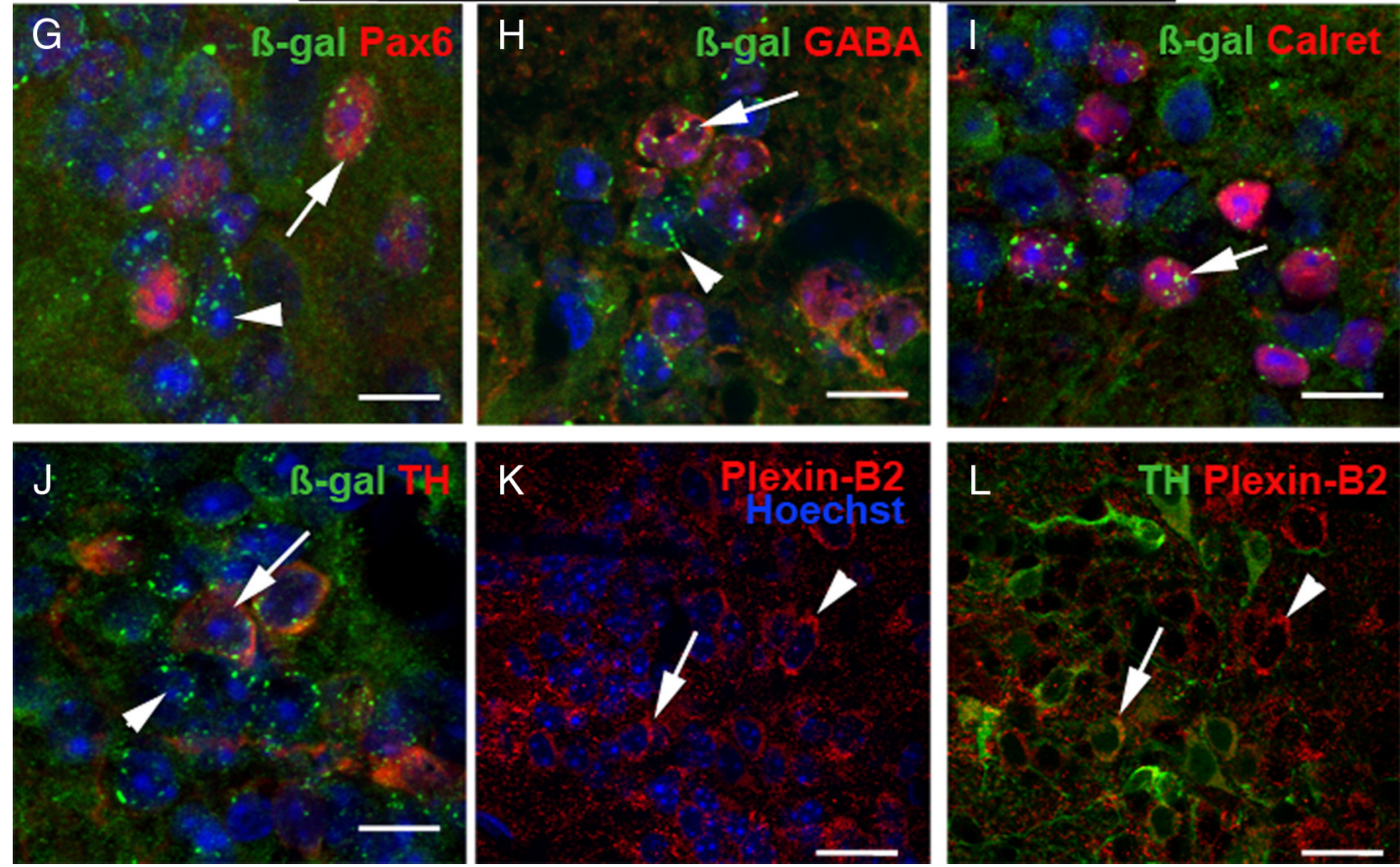

Figure 2. Plexin-B2 is expressed by tangentially migrating neuroblasts and by PG cells. $A-D$, Sagittal sections at the level of the $0 B$ of a P7 mice electroporated at P2 in the SVZ with a GFP-plasmid and immunostained with an anti-Plexin-B2 antibody. Plexin-B2 is highly expressed in the RMS containing tangentially migrating GFP + neuroblasts. $C_{,} C^{\prime}$ is an example of migrating neuroblasts expressing GFP in the cytosol and Plexin-B2 at the cell surface (asterisks). The arrowheads point to the tip of labeled leading processes. Plexin-B2 expression is downregulated in the granular cell layer $(G C L)$, which contains radially migrating GFP + cells $(\boldsymbol{D}$, arrowhead). $E, F$, Sagittal section of the adult $0 B$ immunostained with anti-Plexin-B2 and counterstained with Hoechst. Plexin-B2 is detected in the RMS, in the mitral cell layer (MCL), and in the glomerular cell layer (GL), but not in the granule cell layer (GCL). $F$ shows that adult mitral cells are immunoreactive for Plexin-B2. $\mathbf{G}-\mathbf{L}$ are sections of the adult $\mathrm{OB}$ of $P / x n b 2^{+/-}(\mathbf{G}-J)$ or wild-type mice, at the level of the glomerular layer. In $P / x n b 2^{+/-}(\mathbf{G}-J) 0 B, \beta$-galactosidase is detected in all the different subtypes of periglomerular cells expressing Pax6 ( $G$, arrow), GABA (H, arrow), calretinin $(\boldsymbol{I}$, arrow), and TH $(\boldsymbol{J}$, arrow). Likewise, TH-positive $P G$ cells are immunoreactive for Plexin-B2 $(\boldsymbol{L}$, arrow). In all panels, the arrowheads indicate cells that express $\beta$-gal or Plexin-B2 and are not labeled with the other markers. Scale bars: $\boldsymbol{A}, \boldsymbol{B}, 160 \mu \mathrm{m} ; \boldsymbol{C}, \boldsymbol{C}^{\prime}, 22 \mu \mathrm{m} ; \boldsymbol{D}, 34 \mu \mathrm{m} ; \boldsymbol{E}, 70 \mu \mathrm{m} ; \boldsymbol{F}, 30 \mu \mathrm{m} ; \boldsymbol{K}, \boldsymbol{L}, 20 \mu \mathrm{m}$. 

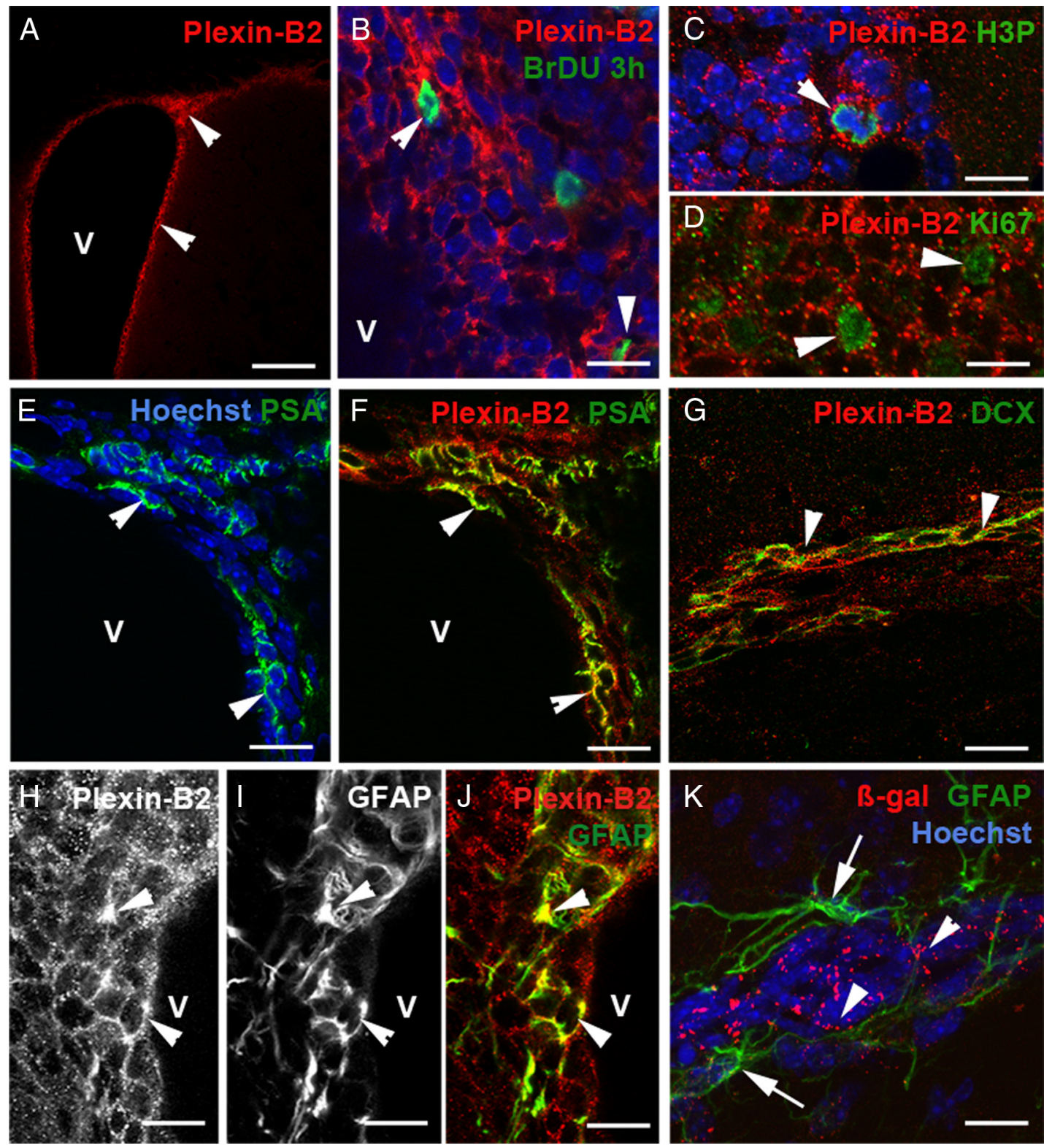

Figure 3. Plexin-B2 expression in the different cell populations of the adult SVZ and RMS. $A$ is a coronal section of the forebrain at the level of the SVZ. SVZ cells lining the ventricle (V) strongly express Plexin-B2 (arrowheads). $\boldsymbol{B}-\boldsymbol{D}$, Rapidly proliferating type ( cells labeled with a short-pulse of BrdU (B), phosphohistone 3 (H3P) (C), and Ki67 (D) are immunoreactive for Plexin-B2 (arrowheads). $\boldsymbol{E}-\mathbf{G}$, Plexin-B2 is also expressed by migrating neuroblasts labeled with PSA-NCAM in the SVZ ( $\boldsymbol{E}, \boldsymbol{F}$, arrowheads) and by DCX in the RMS ( $\boldsymbol{G}$, arrowheads). $\boldsymbol{H}-\boldsymbol{K}$, In the SVZ, GFAP + cells express Plexin-B2 (H-J, arrowheads) but GFAP astrocytes ( $\boldsymbol{K}$, arrows) ensheathing migrating neuroblasts (visualized by Hoechst staining) in the RMS do not express $\beta$-gal in Plxnb2 ${ }^{+/}-$mice. Scale bars: $A, 100 \mu \mathrm{m} ; \boldsymbol{B}, 12 \mu \mathrm{m} ; \boldsymbol{C}, \boldsymbol{D}, 7 \mu \mathrm{m} ; \boldsymbol{E}, \boldsymbol{F}, \boldsymbol{K}, 15 \mu \mathrm{m} ; \boldsymbol{G}, 25 \mu \mathrm{m} ; \boldsymbol{H}-J, 14 \mu \mathrm{m}$.

(GABA or dopamine) and the expression of several calcium binding proteins (Ribak et al., 1977; Halász et al., 1985; De Marchis et al., 2007; Parrish-Aungst et al., 2007). To determine whether all periglomerular cells express Plexin-B2, OB sections from Plxnb2 ${ }^{+/-}$mice were double labeled for $\beta$-galactosidase and calretinin, GABA, TH, or Pax6 and analyzed by confocal microscopy (Fig. $2 G-J$ ). Coexpression with $\beta$-gal was observed in all cases, suggesting that all subtypes of periglomerular cells express Plexin-B2. Likewise, PG cells were also immunoreactive for Plexin-B2 (Fig. $2 K, L$ ) (data not shown).

Previous studies have revealed that the SVZ is a heterogeneous cellular mosaic, containing slowly dividing astrocytes (or type B cells), which have stem cell properties and are the source of neuroblasts (or type A cells) that migrate along the RMS to generate GC and PG cells following a final round of division (Doetsch et al., 1997; Mirzadeh et al., 2008). To better characterize Plexin-B2expressing cells in adult mice, we performed double immunostaining for $\beta$-gal or Plexin-B2 and several markers of SVZ/RMS cells (Doetsch et al., 1997). Plexin-B2 was highly expressed in the SVZ lining the ventricular wall (Fig. 3A). Type $\mathrm{C}$ cells are rapidly dividing cells that can be labeled by a short pulse of BrdU (Doetsch et al., 1997). The combination of short-term BrdU (3 h pulse) (see Materials and Methods) and Plexin-B2 immunostaining showed that type $\mathrm{C}$ cells express Plexin-B2 (Fig. 3B). This was further confirmed by double immunostaining for Plexin-B2 and phosphohistone 3 (H3P), a marker of mitotic cells (Fig. 3C), and Ki67, a marker or proliferating cells (Fig. 3D). In the SVZ and RMS, PlexinB2-immunoreactive cells also expressed PSA-NCAM and Doublecortin (DCX), two markers of migrating neuroblasts, or type A cells (Fig. 3E-G). GFAP-positive cells close to the ventricle appeared 

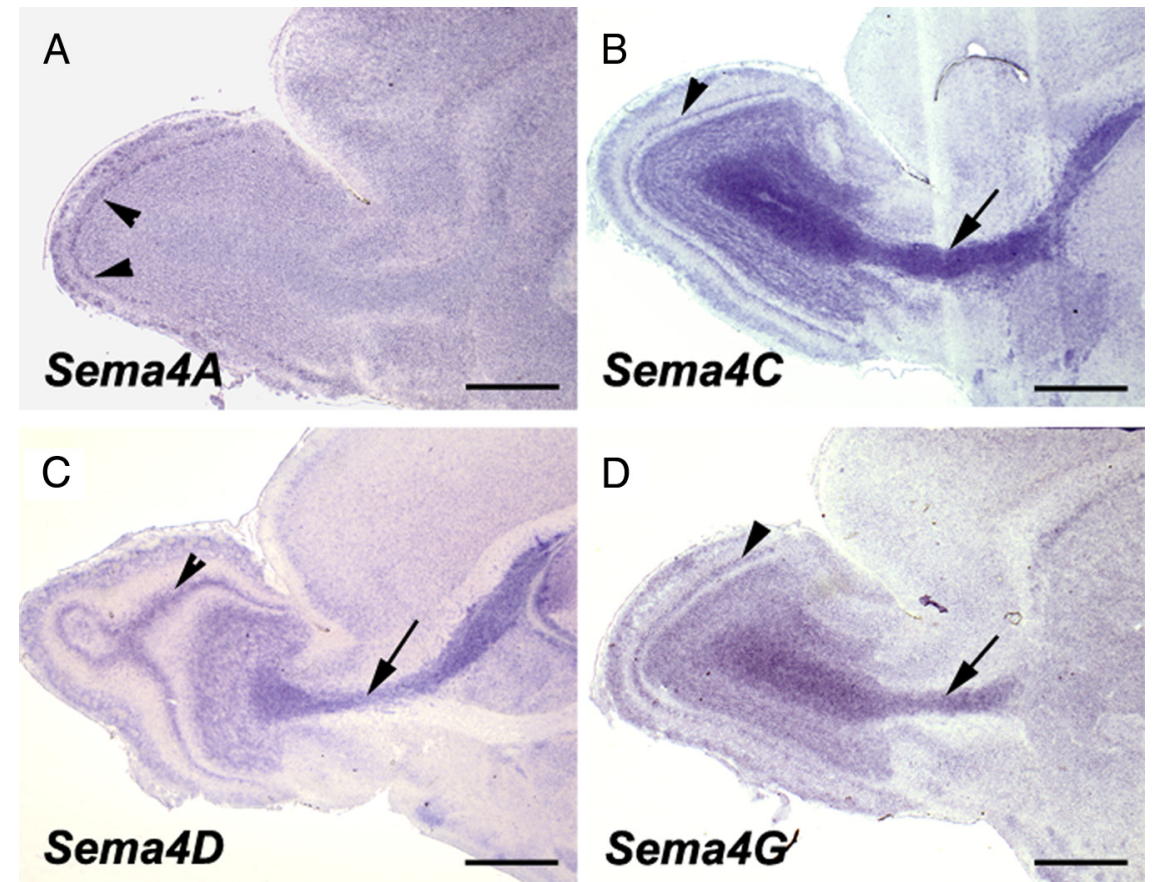

Figure 4. Expression of class IV semaphorins in the postnatal OB. Sagittal sections through the $O B$ and RMS of P8 mice hybridized with riboprobes for Sema4A (A), Sema4C (B), Sema4D (C), and Sema4G (D), the four class IV semaphorins known to bind to Plexin-B2. All semaphorins are expressed in the mitral cell layer (arrowheads). Sema4C, $4 D$, and $4 G$ are also expressed in the RMS (arrow) and GCL. Scale bars, $600 \mu \mathrm{m}$.

to be immunolabeled with anti-Plexin-B2, suggesting that this receptor could be expressed by type B cells (Fig. $3 H-J$ ). By contrast, neither $\beta$-gal nor Plexin-B2 were detected in GFAP-positive astrocytes that ensheath migrating neuroblasts. We next studied the expression pattern, in the forebrain of P8 mice, of the four class IV semaphorins that were previously shown to bind Plexin-B2 namely Sema4A, Sema4C, Sema4D, and Sema4G (Oinuma et al., 2004; Deng et al., 2007; Yukawa et al., 2010b; Maier et al., 2011; Perälä et al., 2011). This showed that Sema4C, $4 \mathrm{D}$, and $4 \mathrm{G}$ are all expressed in the RMS and in the GCL (Fig. 4) and that all four Semaphorins are expressed in the mitral cell layer (Fig. 4).

These results show that Plexin-B2 is broadly expressed in SVZ cells and their derivatives migrating in the RMS together with its semaphorin ligands.

\section{The generation of new neurons is compromised in Plxnb2 - mice}

It was previously observed that the formation of the OB layers is delayed in embryos from another line of Plxnb2 knock-out (Deng et al., 2007). To determine whether this is maintained in the adult, we first measured the OB volume (see Materials and Methods) and did not find any significant differences between heterozygote $\left(11.5 \pm 1.49 \mathrm{~mm}^{3} ; n=3\right)$ and Plxnb2 $2^{-1-}$ animals (9.61 \pm $\left.1.41 \mathrm{~mm}^{3} ; p>0.05 ; n=3\right)$. However, Hoechst staining on $\mathrm{OB}$ coronal sections indicated that $\mathrm{OB}$ layering was largely comparable with control (Fig. $5 A-D$ ) with the notable exception of the mitral cell layer and inner plexiform layer, which were not clearly distinguishable in Plxnb2 $2^{-1-}$ mice ( $n=5$ of 5; Fig. $5 A-D$ ).

Previous studies have shown that Plexin-B2 controls the balance between proliferation and differentiation of cerebellar granule cells (Friedel et al., 2007) and that it may also influence the proliferative potential of embryonic cortical precursors (Hirschberg et al., 2010). Therefore, we next tested whether the proliferation of SVZ cells is perturbed in adult
Plxnb2 $2^{-1-}$ mice. As previously described, a majority of Plxnb2-1- mutant animals die in utero, but those that reach birth survive normally and do not exhibit obvious behavioral deficits (Friedel et al., 2007). We first used the cell division marker BrdU to quantify proliferation in Plxnb2 $2^{+-}$and Plxnb2 $2^{-1-}$ mice. A single BrdU injection was given to adult Plxnb2 $2^{+1-}(n=3)$ and Plxnb2 $2^{-1-}$ mice $(n=3)$ and the mice were perfused $3 \mathrm{~h}$ later. The number of BrdU-positive cells was compared at four rostrocaudal levels of the SVZ-RMS-OB pathway (Fig. 5E). BrdU immunohistochemistry revealed a significant decrease in the number of proliferating cells in $P l \times n b 2^{-1-}$ homozygous mutants compared with heterozygotes (Fig. 5F-H). This reduction of cell proliferation was significant at all levels along the RMS (unpaired two-tailed $t$ test; $p<0.05$ in the $\mathrm{OB}, p<$ 0.001 in other regions), but was more pronounced in the caudal ventricular region $(-44 \%)$ and rostral ventricle $(-39 \%)$ than in the transition region $(-30 \%)$ or the $\mathrm{OB}(-27 \%)$. This suggests that, in the absence of Plexin-B2, SVZ/RMS cell proliferation is more perturbed caudally in the rostrocaudal axis of the RMS-SVZ.

The absence of Plexin-B2 mutation affects the generation of periglomerular cells more severely than that of granule cells After reaching the olfactory bulb, migratory neuroblasts leave the RMS and finally differentiate into granule cells or periglomerular cells. To study the long-term effect of Plexin-B2 absence on adult SVZ-derived cells, we next performed a long-term (30 d) BrdU incorporation assay (Fig. 6). In both Plxnb2 $2^{+1-}(n=3)$ and Plxnb2 $2^{-1-}(n=3)$ adult mice, BrdU-labeled cells were detected in the GC and PG cell layers 1 month after injection (Fig. 6A, $B$ ) (data not shown). However, the number of labeled cells in both layers was significantly reduced in Plxnb2 ${ }^{-1-}$ OB $(151 \pm 15$ GC cells per section in Plxnb2 $2^{+/-}$vs $108 \pm 9$ in Plxnb2 $2^{-1-} ; p<$ 0.001 and $12.9 \pm 1.2 \mathrm{PG}$ cells per section in Plxnb2 $2^{+/-}$vs $6.7 \pm$ 0.6 in Plxnb2 $2^{-1-}$; $p<0.001$; Fig. $\left.6 C, D\right)$ as expected from the decrease in cell proliferation. This reduction was more pronounced for PG cells $(-51 \%)$ than for GC cells $(-35 \%)$. In addition, the ratio between the average number of $\mathrm{GC}$ and $\mathrm{PG}$ cells per $\mathrm{OB}$ section was lower in Plxnb2 $2^{+/-}(11.8: 1 ; n=3,15$ sections from each animal) than in $P l x n b 2^{-1-}$ mice $(16.2: 1 ; n=3,15$ sections from each animal). This suggests that PG cells are more affected than GC cells by the lack of Plexin-B2. Accordingly, the quantification of the number of calretinin-positive cells in the PG layer showed a $19.5 \%$ reduction in $P l \times n b 2^{-1-}$ mice compared with Plxnb2 $2^{+/-}$mice $(1144 \pm 24$ vs $1420 \pm$ 194 calretinin + PG cells, respectively, 3 brains, 10 sections per brain).

The morphology of the newly generated OB interneurons was also analyzed in animals electroporated with GFP at P2 and perfused 20 d later ( $n=2$ animals in both cases). In both Plxnb2 $2^{+1-}$ and Plxnb2 $2^{-1-}$ mice, GFP-expressing cells were observed in the GC layer and their gross morphology was comparable (Fig. 6E,F). Similarly, PG cells looked similar (Fig. 6G,H) and most 

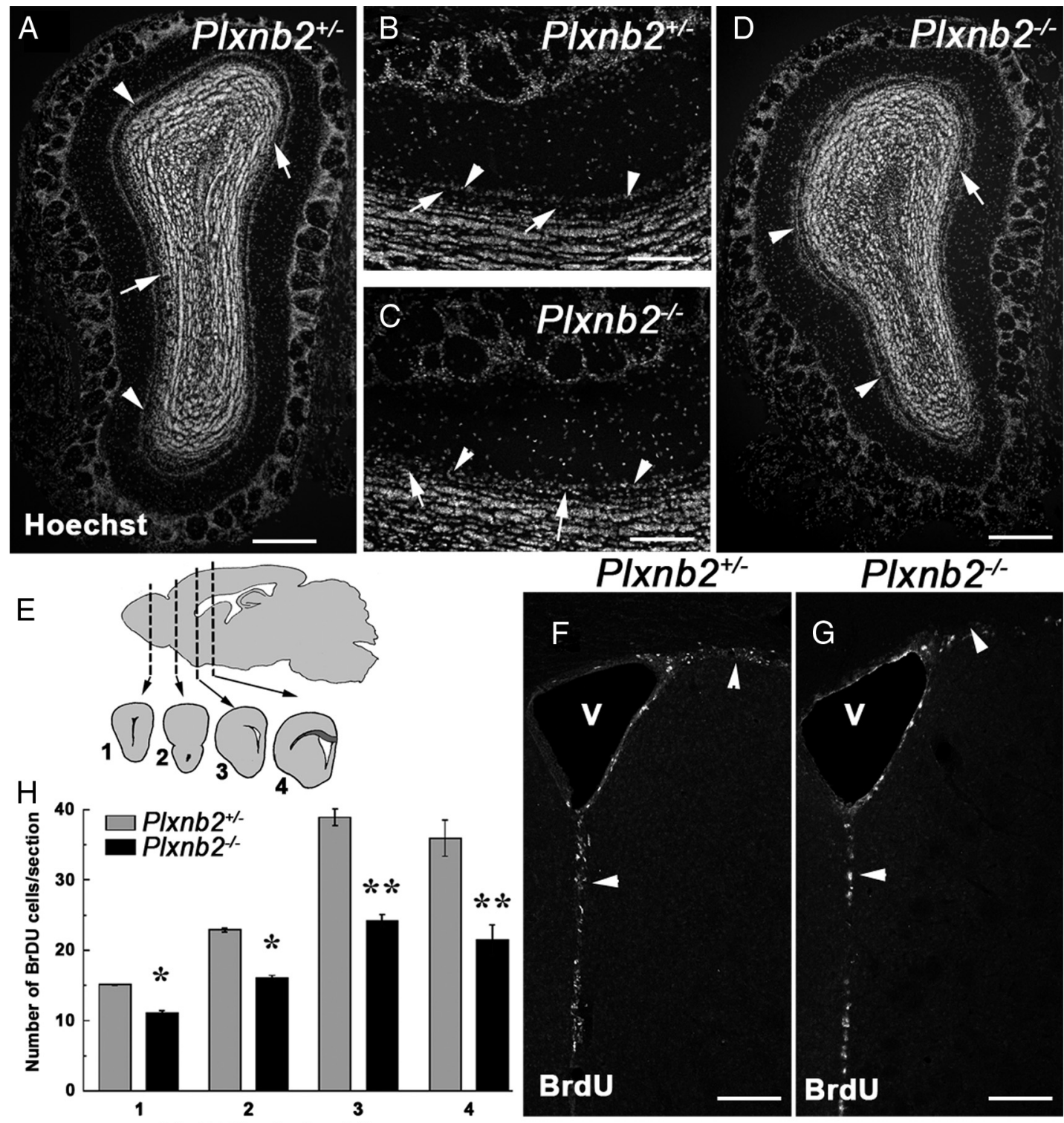

Figure 5. Perturbed $O B$ layering and proliferation in $P / x n b 2$ mutant. $A-D$ are coronal sections of the $O B$ of adult $P / x n b 2^{+/-}(A, B)$ or $P / x n b 2^{-/-}(C, D)$ stained with Hoechst. Whereas in the $P \mid x n b 2^{+1-} O B(A, B)$ the mitral cell layer (arrowheads) is well separated from the granule cell layer by the cell-free inner plexiform layer (arrows), in Plxnb2 $2^{-1-} 0 B(\boldsymbol{C}, \boldsymbol{D})$ the two layers are not clearly delineated/distinguishable. $\boldsymbol{E}-\boldsymbol{H}$ illustrate that proliferation is reduced in the adult SVZ of Plxnb2 ${ }^{-1}$ - mice. $\boldsymbol{E}$, BrdU-positive cells ( $3 \mathrm{~h}$ pulse) were counted at four different rostrocaudal levels along the RMS/SVZ as shown on the schematic. $F$ and $\boldsymbol{G}$ are representative pictures of $P / x n b 2^{+\prime-}$ and $P / x n b 2^{-1-}$ mice showing BrdU + cells in the SVZ. $\boldsymbol{H}, Q$ Quantification of the number of BrdU + cells per section. A significant reduction of BrdU + cells is observed in the mutant. Error bars indicate SEM. ${ }^{*} p<0.05 ; *^{* *} p<0.001$. Scale bars: $\boldsymbol{A}, \boldsymbol{D}, 500 \mu \mathrm{m} ; \boldsymbol{B}, \boldsymbol{C}, 250 \mu \mathrm{m} ; \boldsymbol{F}, \mathbf{G}, 180 \mu \mathrm{m}$.

arborized in a single glomerulus. We counted the ratio of GFP+ GC/GFP+ PG cells both in Plxnb2 $2^{+1-}$ and Plxnb2 $2^{-1-}$ mice $30 \mathrm{~d}$ after electroporation and found an increase in the GC/PG ratio in mutant mice (10.5:1 in Plxnb2 ${ }^{+1-}$ mice and 13.3:1 in Plxnb2 $2^{-1-}$ mice), which confirmed that PG cells are more affected than GCs by the lack of Plexin-B2.

The transition from tangential to radial migration is accelerated in Plxnb2 ${ }^{-1-} \mathrm{OBs}$

To determine whether the migration of Plexin-B2-deficient neuroblasts was perturbed, we next analyzed the distribution of BrdU-labeled cells in the OB, $4 \mathrm{~d}$ after injection $\left(n=3\right.$ mice for Plxnb2 ${ }^{+1-}$ and $\left.P l x n b 2^{-1-}\right)$. We found that a higher proportion of the BrdU-labeled cells had reached the $\mathrm{OB}$ in $\mathrm{Plxnb2}^{-1-}(73 \%)$ than in Plxnb2 ${ }^{+1-}$ mice (63.5\%). In Plxnb2 ${ }^{+/-}$mice, $\sim 95 \%$ of these BrdU+ cells were localized in the RMS (in Fig. $7 A, B$ ) and only $5 \%$ had migrated radially out of the RMS. By contrast, in the Plxnb2 $2^{-1-}$ mice, only $87.5 \%$ of BrdU-positive cells were found in the RMS of the OB and $>12.5 \%$ were detected in more superficial layers, corresponding to a $85 \%$ $(p<0.001)$ increase compared with Plxnb2 ${ }^{+1-}$ mice (Fig. 7C-E).

Interestingly, in control mice, BrdU-labeled cells were confined to the SVZ-RMS-OB pathway, whereas in Plxnb2 ${ }^{+1-}$ mice, a subset of BrdU+ cells was detected in the corpus callosum and septum (data not shown). These ectopic cells also expressed PSA-NCAM and $\beta$-gal, suggesting that some neuroblasts migrated in an aberrant direction in Plxnb2 $2^{-1-}$ mice.

To confirm that newly generated OB neurons left the RMS more rapidly, $\mathrm{P} 2 \mathrm{Plxnb2} 2^{+1-}$ and Plxnb2 $2^{-1-}$ mice were electroporated in the SVZ with a plasmid encoding GFP (see above and Materials and Methods). Electroporated animals were perfused $5 \mathrm{~d}$ after electroporation and the localization of GFP + cells in the $\mathrm{OB}$ was analyzed. In

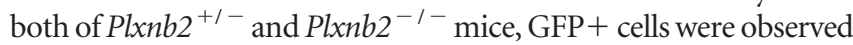



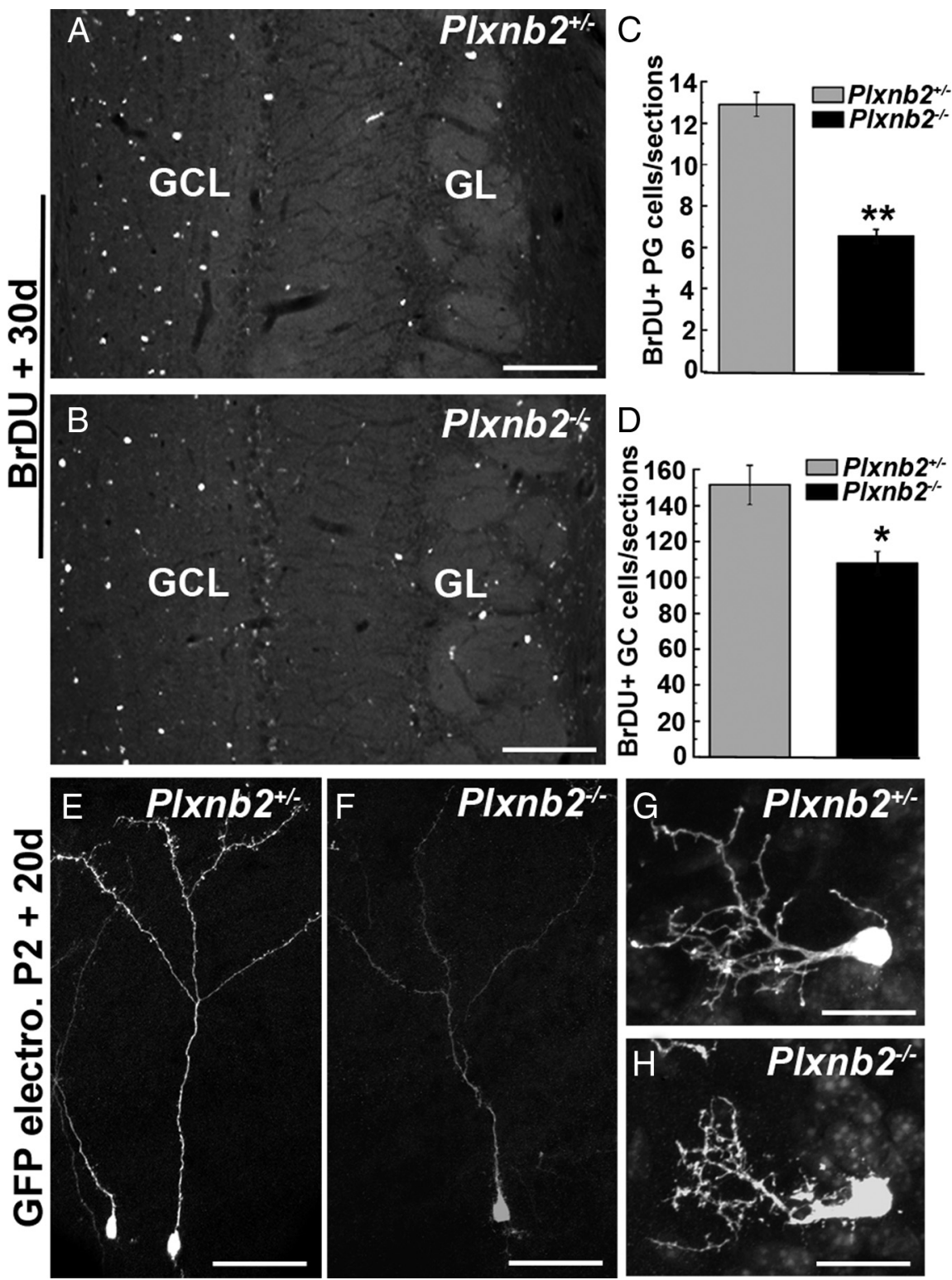

Figure 6. Long-term labeling of newly generated $O B$ neurons in $P / x n b 2$ mutant. $\boldsymbol{A}$ and $\boldsymbol{B}$ are sections of the $O B$ of adult $P / x n b 2^{+1-}$ and Plxnb2 $2^{-1-}$ mice $30 \mathrm{~d}$ after an injection of BrdU. In both cases, BrdU + cells are found in the granule cell layer $(G C L)$ and glomerular cell layer (GL). C, D, The quantification of the number of BrdU + cells reveals a significant decrease in the number of BrdU + PG $(\boldsymbol{C})$ and $G C(\boldsymbol{D})$ cells in P/xnb2 mutant mice. Error bars indicate SEM. $\boldsymbol{E}-\boldsymbol{H}$ are sagittal section at the level of the $O B$ of P22 Plxnb2 $2^{+1-}$ and Plxnb2 ${ }^{-1-}$ mice electroporated at P2 in the SVZ with a GFP-plasmid. The morphology of GFP $+G C$ cells $(\boldsymbol{E}, \boldsymbol{F})$ and $G F P+P G$ cells $(\boldsymbol{G}, \boldsymbol{H})$ is similar Plxnb2 ${ }^{+1-}$ and Plxnb2 $2^{-1-}$ mice. Scale bars: $\boldsymbol{A}, \boldsymbol{B}, 220 \mu \mathrm{m} ; \boldsymbol{E}, \boldsymbol{F}, 300 \mu \mathrm{m} ; \boldsymbol{G}, \boldsymbol{H}$, $20 \mu \mathrm{m}$.

along the RMS and in the OB $\left(n=5\right.$ of 5 Plxnb2 $2^{+/-}$and 4 of 4 in $P l x n b 2^{-I^{-}}$). The quantification of the percentage of GFP+ cells that had left the RMS (to initiate radial migration) versus the total number of GFP cells per section, also showed that there was a very significant increase of radially migrating cells outside the RMS in Plxnb2 $2^{-1-}$ mice (13.18 $\pm 1.73 \% ; n=2$ animals) compared with $P l \times n b 2^{+/-}$mice (5.61 $\pm 0.73 \% ; n=4 ; p<0.0001$ ) (Fig. $7 F-I)$. Incidentally, in GFPelectroporated Plxnb2 $2^{-1-}$ animals, but not in Plxnb2 $2^{+1-}$ mice, GFPexpressing cells were found in the septum region, thus reconfirming the BrdU short-term labeling data (data not shown).

The migration speed of postnatal neuroblasts is increased in Plxnb2 mutants

Although the morphology of migrating neuroblasts appeared normal in Plxnb2 $2^{-1-}$ mice (Figs. 7I, 8) (data not shown), BrdU pulse labeling and GFP electroporation suggested that, in the OB, SVZ-derived cells leave the RMS more rapidly in Plxnb2 $2^{-1-}$ than in $P l x n b 2^{+/-}$mice. To determine whether this could be correlated with a faster migration, we performed time-lapse video-microscopy analysis of GFP-labeled cells in the RMS of forebrain slices from P6/P7 mice electroporated $4-5 \mathrm{~d}$ earlier (Fig. $8 A, B$ ). For each time-lapse sequence, images were taken at $4 \mathrm{~min}$ intervals. We first measured the speed of migrating neuroblasts (30 cells from 6 animals in Plxnb2 $2^{+/-}$and 30 cells from 4 Plxnb2 $2^{-1-}$ mice were tracked) and found that they moved significantly faster in Plxnb2 $2^{-1-}$ RMS slices with an average speed of $113 \pm 25 \mu \mathrm{m} / \mathrm{h} \mathrm{com}-$ pared with $80 \pm 18 \mu \mathrm{m} / \mathrm{h}$ for Plxnb2 $2^{+/-}$ neuroblasts (Fig. $8 D$ ), corresponding to a $40 \%$ increase of the speed in mutants. As reported earlier (Sawamoto et al., 2006; Hirota et al., 2007; Nam et al., 2007; Bagley and Belluscio, 2010), we also observed cells in the RMS moving in either a forward (toward the bulb) or a backward (toward the SVZ) direction, although some cells reversed the direction of their movement during the recording period. In Plxnb2 $2^{+1-}$ mice, $76.1 \%$ cells moved forward and $23.9 \%$ backward [a similar ratio to that previously described (Sawamoto et al., 2006; Hirota et al., 2007; Bagley and Belluscio, 2010)]. In contrast, there was a slightly higher proportion of neuroblasts moving backward in the mutant $(67.5 \%$ forward and $32.5 \%$ backward). We also observed some cells that moved locally without any particular direction (exploratory cells) and cells that were static during the imaging period ( $\mathrm{Ba}$ gley and Belluscio, 2010). The proportion of cells that were migratory/exploratory/ static (Nam et al., 2007) was calculated, and it was found that the proportion of exploratory versus migratory cells was increased in Plxnb2 $2^{-1-}$ slices $(39.4 \%$ migratory and $21 \%$ exploratory) compared with Plxnb2 $2^{+1-}$ slices (52.4\% migratory and $12.1 \%$ exploratory). In both types of slices, we observed equivalent proportion of static cells $(35.5 \%$ in $P l x n b 2^{+1-}$ and $39.4 \%$ in Plxnb2 $2^{-1-}$ ). The migration speed of the exploratory cells was also measured and the mutant exploratory cells were also found to move significantly faster than heterozygote cells $\left(40.5 \pm 8 \mu \mathrm{m} / \mathrm{h}\right.$ in Plxnb2 $2^{+/}$and $59 \pm 10.2 \mu \mathrm{m} / \mathrm{h}$ in Plxnb2 $\left.2^{-/-} ; p<0.001\right)$.

\section{The migration of SVZ neuroblasts in response to GDNF and} HGF is not modified in Plxnb2 mutants

Plexin-B2 is known to mediate semaphorin signaling by class IV semaphorins. In addition, it was also shown to bind two receptor tyrosine kinases, MET and rearranged during transfection (RET), and to modulate their activation by their respective ligands, HGF and GDNF (Garzotto et al., 2008; Perälä et al., 2011). Previous 

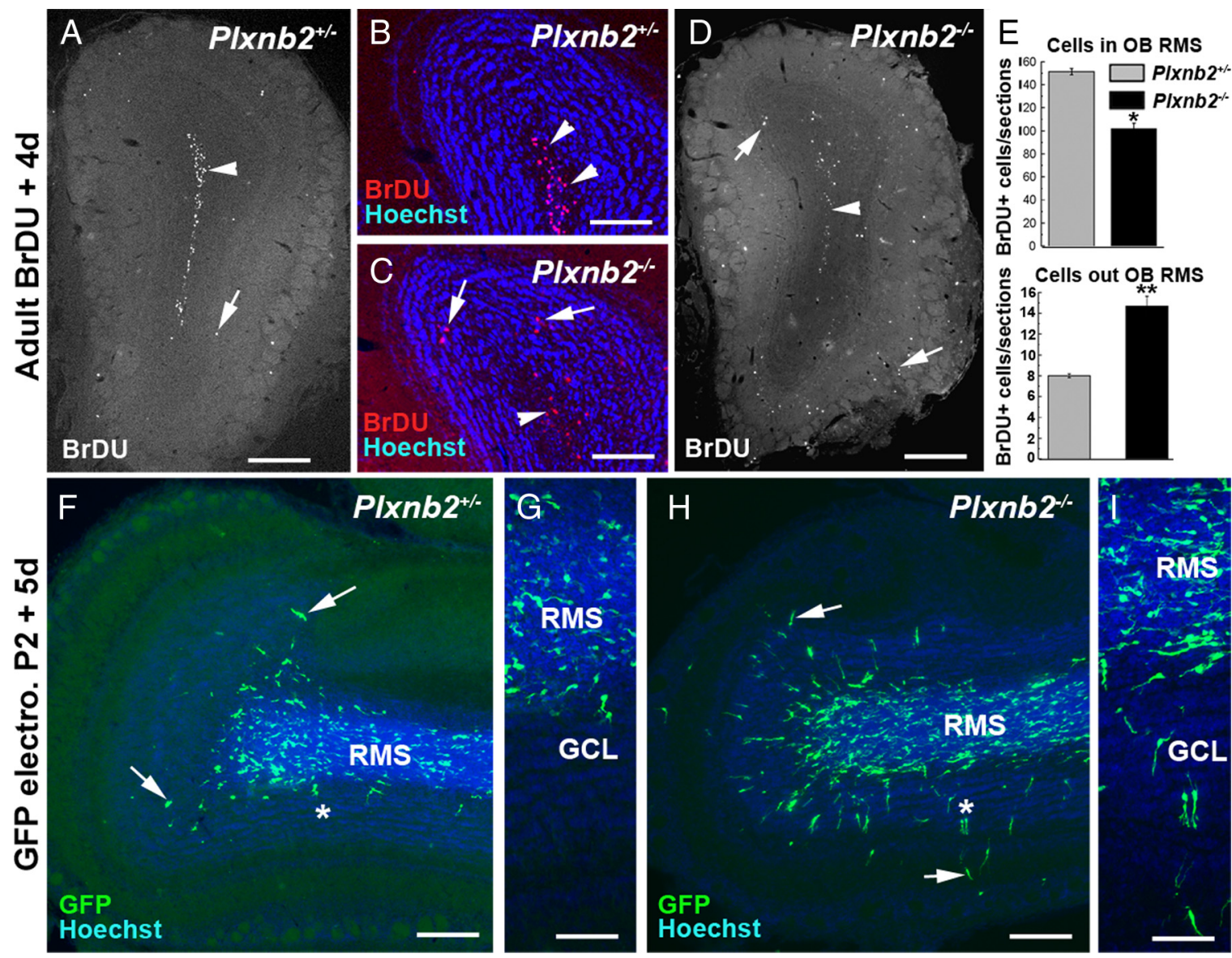

Figure 7. Increased radial migration in the $\mathrm{OB}$ of $P$ Ixnb2 mutants. $A-D$, Coronal sections of the $0 \mathrm{~B}$ of $P / x n b 2^{+/-}(A, B)$ and $P / x n b 2^{-/-}$adult mice $(C, D) 4 \mathrm{~d}$ after an injection of BrdU. In Plxnb2 ${ }^{+-}$, almost all the BrdU + cells are found in the RMS $\left(\boldsymbol{A}, \boldsymbol{B}\right.$, arrowheads) and only a few have entered the GCL $\left(\boldsymbol{A}\right.$, arrow). By contrast, in Plxnb2 ${ }^{-1-}$ mutant, BrdU + cells are found in the RMS (arrowheads) but many have entered the GC layer and PG layer (arrows). $\boldsymbol{B}$ and $\boldsymbol{C}$ are counterstained with Hoechst. $\boldsymbol{E}$ is a quantification of the distribution of BrdU + cells inside and outside of the RMS. In the $0 B$ of Plxnb2 mutant, there is a significant increase in the number of BrdU + cells found outside of the RMS. Error bars indicate SEM. $F-I$ are sagittal sections of the $0 B$ of P7 Plxnb2 ${ }^{+I-}(\boldsymbol{F}, \boldsymbol{G})$ and Plxnb2 $2^{-1-}(\boldsymbol{H}, \boldsymbol{I})$ mice electroporated at P2 in the SVZ with a GFP plasmid. Whereas in Plxnb2 ${ }^{+/-}$only a few GFP + cells have started to migrate into the GCL (arrows), in $P / x n b 2^{-I-}$ mice, many GFP + cells have already left the RMS. $\boldsymbol{G}$ and $\boldsymbol{H}$ are higher magnification pictures of the region indicated by an asterisk in $\boldsymbol{F}$ and $\boldsymbol{I}$ (Hoechst counterstaining). Scale bars: $\boldsymbol{A}$, $D, F, H, 600 \mu \mathrm{m} ; \boldsymbol{B}, C, G, I, 300 \mu \mathrm{m}$.

data suggested that these two receptor/ligand pairs influence migration of SVZ neuroblasts (Paratcha et al., 2006; Garzotto et al., 2008; Wang et al., 2011). Therefore, we next used SVZ explant cultures to determine whether the migratory response of neuroblasts to HGF or GDNF was altered in the absence of Plexin-B2 (Fig. 9). Explants were obtained from P4-P5 RMS and cultured for $36 \mathrm{~h}$ in Matrigel (see Materials and Methods). The number of To-Pro-3 (a nuclear marker)-positive cells that migrated out of the explants in absence of growth factor was not significantly different between wild type (2317.7 $\pm 286 ; n=9$ explants), Plxnb2 ${ }^{+1-}(2960.2 \pm 309.3 ; n=9)$, and Plxnb2 ${ }^{-1-}(3243.8 \pm$ $361.3 ; n=9 ; p>0.05$ ) mutants (Fig. 9).

To determine the optimal dose to elicit a migratory response, HGF or GDNF were next added to wild-type explants at three concentrations: 50, 100, and $200 \mathrm{ng} / \mathrm{ml}$. A significant increase in the number of migrating cells was observed when explants were exposed to $50 \mathrm{ng} / \mathrm{ml} \mathrm{HGF}$ compared with explants cultured without HGF. This boost in migration was not further increased with higher concentrations of HGF (data not shown). The addition of GDNF to wild-type explants did not cause any significant increases in cell migration for any of the concentrations tested (data not shown). Next, explants from Plxnb2 $2^{+/-}(n=9)$ and Plxnb2 ${ }^{-1-}(n=10)$ RMS were cultured with $50 \mathrm{ng} / \mathrm{ml}$ HGF or $200 \mathrm{ng} / \mathrm{ml}$ GDNF. The enhancement of migration upon addition of HGF was equivalent between explants from wild-type and Plxnb2 ${ }^{+/-}$mice (6161.1 \pm 766 cells in wild type vs $5678.6 \pm 616$ in Plxnb2 $\left.2^{+/-} ; p>0.05\right)$. Likewise, there was no significant difference in the total number of migrating cells treated with HGF in Plxnb2 $2^{-1-}$ explants $(6596.6 \pm 820)$ compared with Plxnb2 $2^{+/-}$ $(5678.6 \pm 616 ; p>0.05)$. Last, as in wild type, even at $200 \mathrm{ng} / \mathrm{ml}$, GDNF did not significantly alter the number of cells migrating from explants from Plxnb2 $2^{-1-}$ mutants $(3058.1 \pm 409)$ or Plxnb2 $2^{+/-}(3358.1 \pm 338 ; p>0.05)$.

\section{Discussion}

Plexin-B2 controls adult the proliferation and migration of postnatal SVZ neuroblasts

We show here that RMS neuroblasts deficient for Plexin-B2 migrate more rapidly than control ones. This does not appear to profoundly affect their ability to orient in the RMS as in Plxnb2 mutants there is only a minor increase in the proportion of neuroblasts migrating toward the SVZ rather than the OB. In addition, most of the SVZ-derived neurons reach the OB in Plxnb2 mutants. Accordingly, macrophages and dendritic cells purified from Plxnb2 knock-out mice migrate more rapidly (Roney et al., 2011), and there is a premature migration of granule cells in the Plxnb2 cerebellum (Friedel et al., 2007). Together, these data indicate that Plexin-B2 could provide a molecular tuning mecha- 

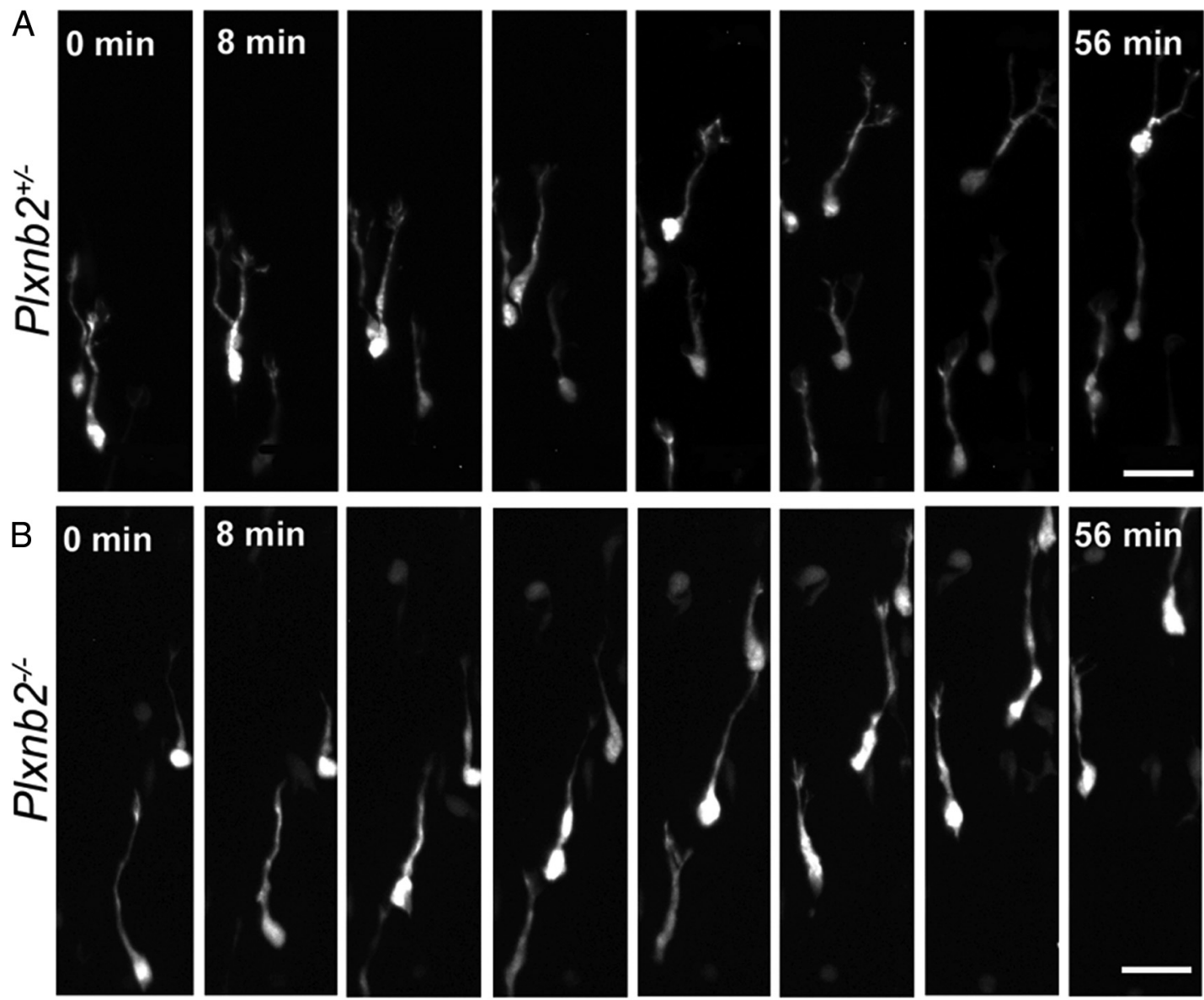

C
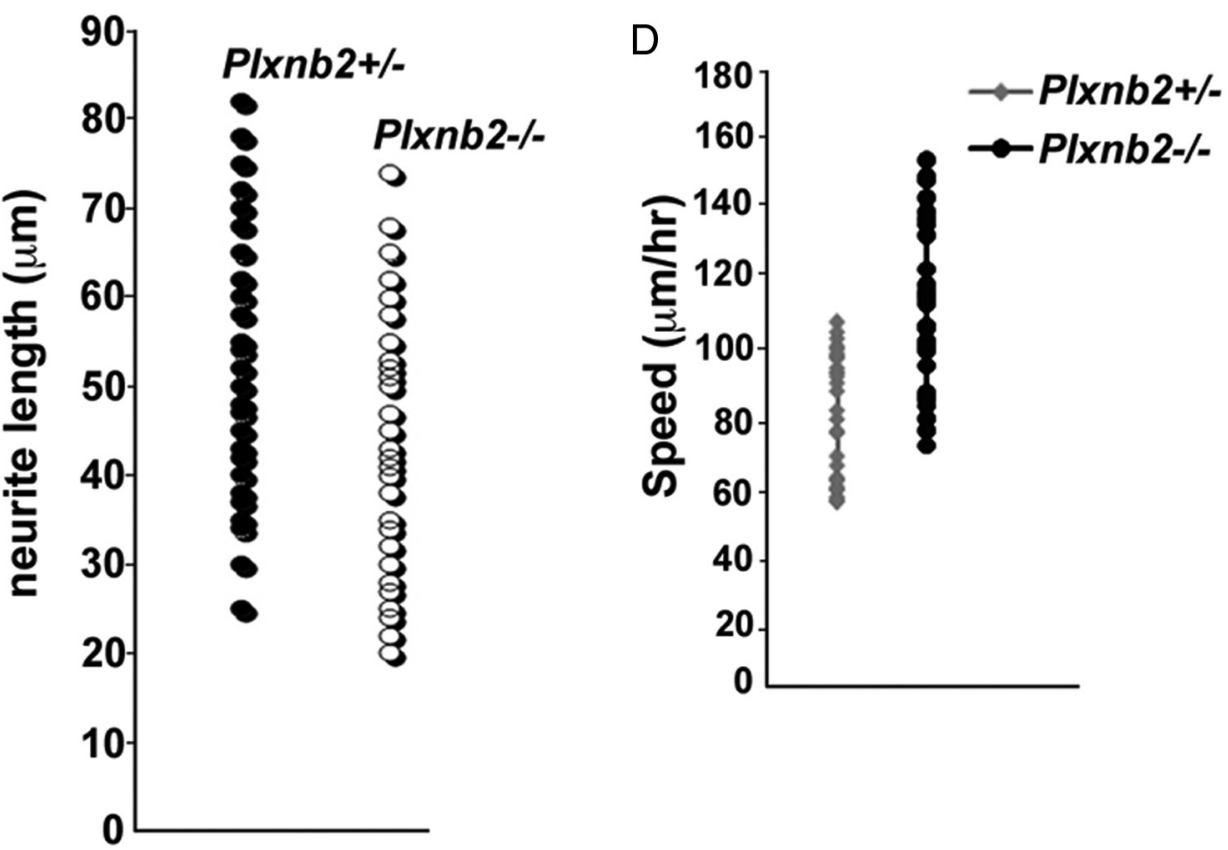

Figure 8. Time-lapse analysis of neuroblast migration. $\boldsymbol{A}, \boldsymbol{B}$, Time-lapse imaging series $(56 \mathrm{~min})$ of migrating neuroblasts in forebrain slices from Plxnb2 ${ }^{+/-}(\boldsymbol{A})$ and Plxnb2 $2^{-/-}(\boldsymbol{B}) \mathrm{P7}$ mice transfected with $\mathrm{pCX}$-GFP and cultured for $1 \mathrm{~h}$ before imaging. The OB is located on the upper side of the frame (interval between pictures is 8 min). $C$ is a comparison of neurite lengths between migrating neuroblasts in the Plxnb2 ${ }^{+1-}$ and $P / x n b 2^{-1-}$ slices. No significant differences in neurite length could be observed. D, Measurement of migration speed of P/xnb2 ${ }^{+1-}$ and P/xnb2 ${ }^{-1-}$ neuroblasts in slices. Plxnb2 mutant neuroblasts move significantly faster along the RMS compared with heterozygote ones. Scale bars, $25 \mu \mathrm{m}$. 
nism allowing migrating cells to control their orientation or decision making at certain choice points.

Our results also show that Plexin-B2 is expressed by the proliferating cells in the adult SVZ-RMS system, which suggests that Plexin-B2 may control their proliferation. In fact, analysis of BrdU incorporation shows a significant reduction in the number of proliferating cells in the SVZ and RMS of Plxnb2 knock-outs. Moreover, the generation of new OB interneurons is compromised in Plxnb2 knockouts with PG cells being more affected than GC cells. These two types of OB interneurons are known to arise from distinct precursors localized preferentially in different domains of the SVZ, and expressing distinct combinations of transcription factors (Merkle et al., 2007; Brill et al., 2008; Weinandy et al., 2011). Although Plexin-B2 appears to be homogeneously expressed along the SVZ, it might act more readily on progenitors of PG interneurons than on those of GC neurons. A role for Plexin-B2 in the control of cell proliferation is supported by previous studies in the developing cortex (Hirschberg et al., 2010) and in the kidney (Perälä et al., 2011). In addition, Plexin-B1 promotes cell proliferation in the immune system (Granziero et al., 2003) and in cancer cell lines (Gómez Román et al., 2008). Interestingly, we showed previously that Plexin-B2 also controls the balance between proliferation and migration in the developing cerebellum (Friedel et al., 2007). In the mutant cerebellum, granule cell precursors leave the external granular layer prematurely but keep dividing during migration. This is somehow reminiscent of OB neuroblasts, which divide as they migrate in the RMS (Smith and Luskin, 1998).

\section{A role for Plexin-B2 controlling the switch from tangential to radial migration?}

Upon reaching the olfactory bulb, newly generated GC and PG cells detach from chains in the RMS and switch to a radial mode of migration to reach their target layers (Whitman and Greer, 2009). Thus far, only a few molecules are known to influence the switch from tangential to radial migration, such as Reelin (Hack et al., 2002; Blake et al., 2008) and the chemokine-like peptide Prokineticin 2 (Ng et al., 2005; Prosser et al., 2007; Puverel et al., 2009). Tenascin-R and Sonic-hedgehog expressed in the RMS and $\mathrm{OB}$ are also able to attract neuroblasts in vitro and in vivo (Saghatelyan et al., 2004; Angot et al., 2008) and may guide them to their target layers. Our results suggest that Plexin-B2 may also play a role in this process. First, there is a striking correlation between the departure/exit of $\mathrm{OB}$ interneurons from the RMS and the downregulation of Plexin-B2 expression in the OB. Second, OB interneurons labeled with BrdU or GFP enter the PG and GC layers more rapidly in Plxnb2 KO than in controls. Last, there are many ectopic cells in the OB IPL of Plxnb2 KO, suggesting that their radial migration could be affected. The presence of Sema4A, 4C, 4D, and 4G in mitral cells and of Sema4C, 4D, and
4G in the GCL of the OB suggest that these semaphorins may act as a barrier to prevent $\mathrm{OB}$ interneurons from initiating radial migration prematurely.

\section{Is Plexin-B2 a molecular hub in neuronal migration?}

Plexin-B2 is a receptor for class IV semaphorins, but it can also interact with other transmembrane receptors, suggesting that Plexin-B2 could be a molecular hub for a variety of receptors involved in postnatal neurogenesis. At least two non-mutually exclusive mechanisms could explain the defects observed in Plxnb2 KO.

First, we show here that the Plexin-B2 ligands, Sema4C, 4D, and $4 \mathrm{G}$, are expressed in the $\mathrm{OB}$ and along the RMS (Wu et al., 2009), although the lack of antibodies do not allow to determine whether the Semaphorin-expressing cells are ensheathing astrocytes or neuroblasts or both. Therefore, a classic, Semaphorin/ PlexinB2 repulsive mechanism may be at play in the RMS to prevent neuroblasts from prematurely leaving the RMS or from escaping from within its confines. Accordingly, in Plxnb2 KO, a fraction of the neuroblasts migrate ectopically into the septum and corpus callosum (data not shown). Likewise, in the cerebellum of Plxnb2 KO mice, granule cell progenitors initiate radial cell migration ahead of time. Overall, this suggests that Semaphorin/Plexin-B2 signaling may inhibit radial migration in the CNS. Semaphorin could as well polarize the tangential migration within the RMS according to the so-called surround repul- 
sion model (Keynes et al., 1997), forcing neuroblasts to migrate along the caudorostral axis. This could explain the higher proportion of exploratory and possibly disoriented cells in the mutant RMS. It will be required to directly confirm in vivo that class IV semaphorins are involved in this process. However, out of six class IV semaphorins that were identified in rodents, at least four, Sema4A, Sema4C, Sema4D, and Sema4G, can bind to Plexin-B2 (Oinuma et al., 2004; Deng et al., 2007; Yukawa et al., 2010a; Maier et al., 2011; Perälä et al., 2011). These semaphorins most likely act redundantly as neither Sema4a, Sema4d, Sema4c, or Sema4g single knock-outs nor Sema4A/Sema4d or Sema4c/ Sema4c double knock-outs phenocopy the severe cerebellar defects found in Plxnb2 knock-outs (Friedel et al., 2007; Maier et al., 2011).

In the second hypothetical model, the lack of Plexin-B2 could perturb signaling downstream of receptor tyrosine kinases. Plexin-B2 binds to receptor tyrosine kinases such as ErbB-2 and Met and is phosphorylated by these receptors upon semaphorin binding (Giordano et al., 2002; Conrotto et al., 2004, 2005; Swiercz et al., 2004, 2009; Deng et al., 2007). Met is also expressed by SVZ neuroblasts (Garzotto et al., 2008), and its ligand HGF promotes their motility and their proliferation (Nicoleau et al., 2009; Wang et al., 2011). However, results from our in vitro cultures show that the number of cells migrating out of Plxnb2 $2^{-1-}$ RMS explants in the presence of HGF is similar to that in controls. This suggests that Plexin-B2 might not regulate HGF response in postnatal neuroblasts. Plexin-B2 also interacts with the RET receptor (Perälä et al., 2011), and Plexin-B2-deficient ureteric buds fail to respond to the RET ligand GDNF. Postnatal neuroblasts were previously shown to respond to GDNF (Kobayashi et al., 2006; Paratcha et al., 2006), but in our assay (where GDNF concentration is homogeneous around the explants) we observed no effect of GDNF on neuroblast migration.

Although these models will need to be tested in vivo, our data suggest that Semaphorins are the ligands of Plexin-B2 in postnatal neurogenesis and migration.

\section{References}

Angot E, Loulier K, Nguyen-Ba-Charvet KT, Gadeau AP, Ruat M, Traiffort E (2008) Chemoattractive activity of sonic hedgehog in the adult subventricular zone modulates the number of neural precursors reaching the olfactory bulb. Stem Cells 26:2311-2320. CrossRef Medline

Artigiani S, Conrotto P, Fazzari P, Gilestro GF, Barberis D, Giordano S, Comoglio PM, Tamagnone L (2004) Plexin-B3 is a functional receptor for semaphorin 5A. EMBO Rep 5:710-714. CrossRef Medline

Bagley JA, Belluscio L (2010) Dynamic imaging reveals that brain-derived neurotrophic factor can independently regulate motility and direction of neuroblasts within the rostral migratory stream. Neuroscience 169:14491461. CrossRef Medline

Blake SM, Strasser V, Andrade N, Duit S, Hofbauer R, Schneider WJ, Nimpf J (2008) Thrombospondin-1 binds to ApoER2 and VLDL receptor and functions in postnatal neuronal migration. EMBO J 27:3069-3080. CrossRef Medline

Boutin C, Diestel S, Desoeuvre A, Tiveron MC, Cremer H (2008) Efficient in vivo electroporation of the postnatal rodent forebrain. PLoS One 3:e1883. CrossRef Medline

Bovetti S, Bovolin P, Perroteau I, Puche AC (2007) Subventricular zonederived neuroblast migration to the olfactory bulb is modulated by matrix remodelling. Eur J Neurosci 25:2021-2033. CrossRef Medline

Brill MS, Snapyan M, Wohlfrom H, Ninkovic J, Jawerka M, Mastick GS, Ashery-Padan R, Saghatelyan A, Berninger B, Götz M (2008) A dlx2and pax6-dependent transcriptional code for periglomerular neuron specification in the adult olfactory bulb. J Neurosci 28:6439-6452. CrossRef Medline

Carleton A, Petreanu LT, Lansford R, Alvarez-Buylla A, Lledo PM (2003) Becoming a new neuron in the adult olfactory bulb. Nat Neurosci 6:507518. Medline
Chen H, Chédotal A, He Z, Goodman CS, Tessier-Lavigne M (1997) Neuropilin-2, a novel member of the neuropilin family, is a high affinity receptor for the semaphorins Sema E and Sema IV but not Sema III. Neuron 19:547-559. CrossRef Medline

Conover JC, Doetsch F, Garcia-Verdugo JM, Gale NW, Yancopoulos GD, Alvarez-Buylla A (2000) Disruption of Eph/ephrin signaling affects migration and proliferation in the adult subventricular zone. Nat Neurosci 3:1091-1097. CrossRef Medline

Conrotto P, Corso S, Gamberini S, Comoglio PM, Giordano S (2004) Interplay between scatter factor receptors and B plexins controls invasive growth. Oncogene 23:5131-5137. CrossRef Medline

Conrotto P, Valdembri D, Corso S, Serini G, Tamagnone L, Comoglio PM, Bussolino F, Giordano S (2005) Sema4D induces angiogenesis through Met recruitment by Plexin B1. Blood 105:4321-4329. CrossRef Medline

De Marchis S, Bovetti S, Carletti B, Hsieh YC, Garzotto D, Peretto P, Fasolo A, Puche AC, Rossi F (2007) Generation of distinct types of periglomerular olfactory bulb interneurons during development and in adult mice: implication for intrinsic properties of the subventricular zone progenitor population. J Neurosci 27:657-664. CrossRef Medline

Deng S, Hirschberg A, Worzfeld T, Penachioni JY, Korostylev A, Swiercz JM, Vodrazka P, Mauti O, Stoeckli ET, Tamagnone L, Offermanns S, Kuner R (2007) Plexin-B2, but not Plexin-B1, critically modulates neuronal migration and patterning of the developing nervous system in vivo. J Neurosci 27:6333-6347. CrossRef Medline

Doetsch F, García-Verdugo JM, Alvarez-Buylla A (1997) Cellular composition and three-dimensional organization of the subventricular germinal zone in the adult mammalian brain. J Neurosci 17:5046-5061. Medline

Friedel RH, Kerjan G, Rayburn H, Schüller U, Sotelo C, Tessier-Lavigne M, Chédotal A (2007) Plexin-B2 controls the development of cerebellar granule cells. J Neurosci 27:3921-3932. CrossRef Medline

Garzotto D, Giacobini P, Crepaldi T, Fasolo A, De Marchis S (2008) Hepatocyte growth factor regulates migration of olfactory interneuron precursors in the rostral migratory stream through Met-Grb2 coupling. J Neurosci 28:5901-5909. CrossRef Medline

Ghashghaei HT, Lai C, Anton ES (2007) Neuronal migration in the adult brain: are we there yet? Nat Rev Neurosci 8:141-151. CrossRef Medline

Giacobini P, Messina A, Morello F, Ferraris N, Corso S, Penachioni J, Giordano S, Tamagnone L, Fasolo A (2008) Semaphorin 4D regulates gonadotropin hormone-releasing hormone-1 neuronal migration through PlexinB1-Met complex. J Cell Biol 183:555-566. CrossRef Medline

Giordano S, Corso S, Conrotto P, Artigiani S, Gilestro G, Barberis D, Tamagnone L, Comoglio PM (2002) The semaphorin 4D receptor controls invasive growth by coupling with Met. Nat Cell Biol 4:720-724. CrossRef Medline

Gómez Román JJ, Garay GO, Saenz P, Escuredo K, Sanz Ibayondo C, Gutkind S, Junquera C, Simón L, Martínez A, Fernández Luna JL, Val-Bernal JF (2008) Plexin B1 is downregulated in renal cell carcinomas and modulates cell growth. Transl Res 151:134-140. CrossRef Medline

Granziero L, Circosta P, Scielzo C, Frisaldi E, Stella S, Geuna M, Giordano S, Ghia P, Caligaris-Cappio F (2003) CD100/Plexin-B1 interactions sustain proliferation and survival of normal and leukemic $\mathrm{CD} 5{ }^{+} \mathrm{B}$ lymphocytes. Blood 101:1962-1969. CrossRef Medline

Gu C, Yoshida Y, Livet J, Reimert DV, Mann F, Merte J, Henderson CE, Jessell TM, Kolodkin AL, Ginty DD (2005) Semaphorin 3E and plexin-D1 control vascular pattern independently of neuropilins. Science 307:265268. CrossRef Medline

Hack I, Bancila M, Loulier K, Carroll P, Cremer H (2002) Reelin is a detachment signal in tangential chain-migration during postnatal neurogenesis. Nat Neurosci 5:939-945. CrossRef Medline

Hakanen J, Duprat S, Salminen M (2011) Netrin1 is required for neural and glial precursor migrations into the olfactory bulb. Dev Biol 355:101-114. CrossRef Medline

Halász N, Hökfelt T, Norman AW, Goldstein M (1985) Tyrosine hydroxylase and $28 \mathrm{~K}$-vitamin $\mathrm{D}$-dependent calcium binding protein are localized in different subpopulations of periglomerular cells of the rat olfactory bulb. Neurosci Lett 61:103-107. CrossRef Medline

Hirota Y, Ohshima T, Kaneko N, Ikeda M, Iwasato T, Kulkarni AB, Mikoshiba K, Okano H, Sawamoto K (2007) Cyclin-dependent kinase 5 is required for control of neuroblast migration in the postnatal subventricular zone. J Neurosci 27:12829-12838. CrossRef Medline

Hirschberg A, Deng S, Korostylev A, Paldy E, Costa MR, Worzfeld T, Vodrazka P, Wizenmann A, Götz M, Offermanns S, Kuner R (2010) 
Gene deletion mutants reveal a role for semaphorin receptors of the plexin-B family in mechanisms underlying corticogenesis. Mol Cell Biol 30:764-780. CrossRef Medline

Holmberg J, Armulik A, Senti KA, Edoff K, Spalding K, Momma S, Cassidy R, Flanagan JG, Frisén J (2005) Ephrin-A2 reverse signaling negatively regulates neural progenitor proliferation and neurogenesis. Genes Dev 19: 462-471. CrossRef Medline

Hu H (1999) Chemorepulsion of neuronal migration by Slit2 in the developing mammalian forebrain. Neuron 23:703-711. CrossRef Medline

Ito K, Kawasaki T, Takashima S, Matsuda I, Aiba A, Hirata T (2008) Semaphorin $3 \mathrm{~F}$ confines ventral tangential migration of lateral olfactory tract neurons onto the telencephalon surface. J Neurosci 28:4414-4422. CrossRef Medline

Jankovski A, Sotelo C (1996) Subventricular zone-olfactory bulb migratory pathway in the adult mouse: cellular composition and specificity as determined by heterochronic and heterotopic transplantation. J Comp Neurol 371:376-396. Medline

Jiao JW, Feldheim DA, Chen DF (2008) Ephrins as negative regulators of adult neurogenesis in diverse regions of the central nervous system. Proc Natl Acad Sci U S A 105:8778-8783. CrossRef Medline

Kaneko N, Marín O, Koike M, Hirota Y, Uchiyama Y, Wu JY, Lu Q, TessierLavigne M, Alvarez-Buylla A, Okano H, Rubenstein JL, Sawamoto K (2010) New neurons clear the path of astrocytic processes for their rapid migration in the adult brain. Neuron 67:213-223. CrossRef Medline

Kelsch W, Lin CW, Lois C (2008) Sequential development of synapses in dendritic domains during adult neurogenesis. Proc Natl Acad Sci U S A 105:16803-16808. CrossRef Medline

Kerjan G, Dolan J, Haumaitre C, Schneider-Maunoury S, Fujisawa H, Mitchell KJ, Chédotal A (2005) The transmembrane semaphorin Sema6A controls cerebellar granule cell migration. Nat Neurosci 8:1516-1524. CrossRef Medline

Keynes R, Tannahill D, Morgenstern DA, Johnson AR, Cook GM, Pini A (1997) Surround repulsion of spinal sensory axons in higher vertebrate embryos. Neuron 18:889-897. CrossRef Medline

Kobayashi T, Ahlenius H, Thored P, Kobayashi R, Kokaia Z, Lindvall O (2006) Intracerebral infusion of glial cell line-derived neurotrophic factor promotes striatal neurogenesis after stroke in adult rats. Stroke 37: 2361-2367. CrossRef Medline

Lois C, Alvarez-Buylla A (1994) Long-distance neuronal migration in the adult mammalian brain. Science 264:1145-1148. CrossRef Medline

Lois C, García-Verdugo JM, Alvarez-Buylla A (1996) Chain migration of neuronal precursors. Science 271:978-981. CrossRef Medline

Luskin MB (1993) Restricted proliferation and migration of postnatally generated neurons derived from the forebrain subventricular zone. Neuron 11:173-189. CrossRef Medline

Luskin MB, Parnavelas JG, Barfield JA (1993) Neurons, astrocytes, and oligodendrocytes of the rat cerebral cortex originate from separate progenitor cells: an ultrastructural analysis of clonally related cells. J Neurosci 13:1730-1750. Medline

Maier V, Jolicoeur C, Rayburn H, Takegahara N, Kumanogoh A, Kikutani H, Tessier-Lavigne M, Wurst W, Friedel RH (2011) Semaphorin 4C and 4G are ligands of Plexin-B2 required in cerebellar development. Mol Cell Neurosci 46:419-431. CrossRef Medline

Marillat V, Cases O, Nguyen-Ba-Charvet KT, Tessier-Lavigne M, Sotelo C, Chédotal A (2002) Spatiotemporal expression patterns of slit and robo genes in the rat brain. J Comp Neurol 442:130-155. CrossRef Medline

Marín O, Rubenstein JL (2001) A long, remarkable journey: tangential migration in the telencephalon. Nat Rev Neurosci 2:780-790. CrossRef Medline

Merkle FT, Mirzadeh Z, Alvarez-Buylla A (2007) Mosaic organization of neural stem cells in the adult brain. Science 317:381-384. CrossRef Medline

Mirzadeh Z, Merkle FT, Soriano-Navarro M, Garcia-Verdugo JM, AlvarezBuylla A (2008) Neural stem cells confer unique pinwheel architecture to the ventricular surface in neurogenic regions of the adult brain. Cell Stem Cell 3:265-278. CrossRef Medline

Nam SC, Kim Y, Dryanovski D, Walker A, Goings G, Woolfrey K, Kang SS, Chu C, Chenn A, Erdelyi F, Szabo G, Hockberger P, Szele FG (2007) Dynamic features of postnatal subventricular zone cell motility: a twophoton time-lapse study. J Comp Neurol 505:190-208. CrossRef Medline

Ng KL, Li JD, Cheng MY, Leslie FM, Lee AG, Zhou QY (2005) Dependence of olfactory bulb neurogenesis on prokineticin 2 signaling. Science 308: 1923-1927. CrossRef Medline

Nguyen-Ba-Charvet KT, Picard-Riera N, Tessier-Lavigne M, Baron-Van Evercooren A, Sotelo C, Chédotal A (2004) Multiple roles for slits in the control of cell migration in the rostral migratory stream. J Neurosci 24 : 1497-1506. CrossRef Medline

Nicoleau C, Benzakour O, Agasse F, Thiriet N, Petit J, Prestoz L, Roger M, Jaber M, Coronas V (2009) Endogenous hepatocyte growth factor is a niche signal for subventricular zone neural stem cell amplification and self-renewal. Stem Cells 27:408-419. CrossRef Medline

Oinuma I, Ishikawa Y, Katoh H, Negishi M (2004) The Semaphorin 4D receptor Plexin-B1 is a GTPase activating protein for R-Ras. Science 305: 862-865. CrossRef Medline

Paratcha G, Ibáñez CF, Ledda F (2006) GDNF is a chemoattractant factor for neuronal precursor cells in the rostral migratory stream. Mol Cell Neurosci 31:505-514. CrossRef Medline

Parrish-Aungst S, Shipley MT, Erdelyi F, Szabo G, Puche AC (2007) Quantitative analysis of neuronal diversity in the mouse olfactory bulb. J Comp Neurol 501:825-836. CrossRef Medline

Pasterkamp RJ, Giger RJ (2009) Semaphorin function in neural plasticity and disease. Curr Opin Neurobiol 19:263-274. CrossRef Medline

Perälä N, Jakobson M, Ola R, Fazzari P, Penachioni JY, Nymark M, Tanninen T, Immonen T, Tamagnone L, Sariola H (2011) Sema4C-Plexin B2 signalling modulates ureteric branching in developing kidney. Differentiation 81:81-91. CrossRef Medline

Prosser HM, Bradley A, Chesham JE, Ebling FJ, Hastings MH, Maywood ES (2007) Prokineticin receptor 2 (Prokr2) is essential for the regulation of circadian behavior by the suprachiasmatic nuclei. Proc Natl Acad Sci U S A 104:648-653. CrossRef Medline

Puverel S, Nakatani H, Parras C, Soussi-Yanicostas N (2009) Prokineticin receptor 2 expression identifies migrating neuroblasts and their subventricular zone transient-amplifying progenitors in adult mice. J Comp Neurol 512:232-242. CrossRef Medline

Renaud J, Kerjan G, Sumita I, Zagar Y, Georget V, Kim D, Fouquet C, Suda K, Sanbo M, Suto F, Ackerman SL, Mitchell KJ, Fujisawa H, Chédotal A (2008) Plexin-A2 and its ligand, Sema6A, control nucleus-centrosome coupling in migrating granule cells. Nat Neurosci 11:440-449. CrossRef Medline

Ribak CE, Vaughn JE, Saito K, Barber R, Roberts E (1977) Glutamate decarboxylase localization in neurons of the olfactory bulb. Brain Res 126:1-18. CrossRef Medline

Roney KE, O'Connor BP, Wen H, Holl EK, Guthrie EH, Davis BK, Jones SW, Jha S, Sharek L, Garcia-Mata R, Bear JE, Ting JP (2011) Plexin-B2 negatively regulates macrophage motility, Rac, and Cdc42 activation. PLoS One 6:e24795. CrossRef Medline

Saghatelyan A, de Chevigny A, Schachner M, Lledo PM (2004) Tenascin-R mediates activity-dependent recruitment of neuroblasts in the adult mouse forebrain. Nat Neurosci 7:347-356. CrossRef Medline

Sanai N, Nguyen T, Ihrie RA, Mirzadeh Z, Tsai HH, Wong M, Gupta N, Berger MS, Huang E, Garcia-Verdugo JM, Rowitch DH, Alvarez-Buylla A (2011) Corridors of migrating neurons in the human brain and their decline during infancy. Nature 478:382-386. CrossRef Medline

Sawamoto K, Wichterle H, Gonzalez-Perez O, Cholfin JA, Yamada M, Spassky N, Murcia NS, Garcia-Verdugo JM, Marin O, Rubenstein JL, Tessier-Lavigne M, Okano H, Alvarez-Buylla A (2006) New neurons follow the flow of cerebrospinal fluid in the adult brain. Science 311:629 632. CrossRef Medline

Smith CM, Luskin MB (1998) Cell cycle length of olfactory bulb neuronal progenitors in the rostral migratory stream. Dev Dyn 213:220-227. CrossRef Medline

Snapyan M, Lemasson M, Brill MS, Blais M, Massouh M, Ninkovic J, Gravel C, Berthod F, Götz M, Barker PA, Parent A, Saghatelyan A (2009) Vasculature guides migrating neuronal precursors in the adult mammalian forebrain via brain-derived neurotrophic factor signaling. J Neurosci 29: 4172-4188. CrossRef Medline

Swiercz JM, Kuner R, Offermanns S (2004) Plexin-B1/RhoGEF-mediated RhoA activation involves the receptor tyrosine kinase ErbB-2. J Cell Biol 165:869-880. CrossRef Medline

Swiercz JM, Worzfeld T, Offermanns S (2009) Semaphorin 4D signaling requires the recruitment of phospholipase $\mathrm{C}$ gamma into the plexin- $\mathrm{B} 1$ receptor complex. Mol Cell Biol 29:6321-6334. CrossRef Medline

Takeuchi JK, Mileikovskaia M, Koshiba-Takeuchi K, Heidt AB, Mori AD, 
Arruda EP, Gertsenstein M, Georges R, Davidson L, Mo R, Hui CC, Henkelman RM, Nemer M, Black BL, Nagy A, Bruneau BG (2005) Tbx20 dose-dependently regulates transcription factor networks required for mouse heart and motoneuron development. Development 132:24632474. CrossRef Medline

Tamagnone L, Artigiani S, Chen H, He Z, Ming GI, Song H, Chedotal A, Winberg ML, Goodman CS, Poo M, Tessier-Lavigne M, Comoglio PM (1999) Plexins are a large family of receptors for transmembrane, secreted, and GPI-anchored semaphorins in vertebrates. Cell 99:71-80. CrossRef Medline

Tran TS, Kolodkin AL, Bharadwaj R (2007) Semaphorin regulation of cellular morphology. Annu Rev Cell Dev Biol 23:263-292. CrossRef Medline

Wang TW, Zhang H, Gyetko MR, Parent JM (2011) Hepatocyte growth factor acts as a mitogen and chemoattractant for postnatal subventricular zone-olfactory bulb neurogenesis. Mol Cell Neurosci 48:38-50. CrossRef Medline

Wansleeben C, van Gurp L, Feitsma H, Kroon C, Rieter E, Verberne M, Guryev V, Cuppen E, Meijlink F (2011) An ENU-mutagenesis screen in the mouse: identification of novel developmental gene functions. PLoS One 6:e19357. CrossRef Medline

Weinandy F, Ninkovic J, Götz M (2011) Restrictions in time and spacenew insights into generation of specific neuronal subtypes in the adult mammalian brain. Eur J Neurosci 33:1045-1054. CrossRef Medline

Whitman MC, Greer CA (2009) Adult neurogenesis and the olfactory system. Prog Neurobiol 89:162-175. CrossRef Medline
Worzfeld T, Püschel AW, Offermanns S, Kuner R (2004) Plexin-B family members demonstrate non-redundant expression patterns in the developing mouse nervous system: an anatomical basis for morphogenetic effects of Sema4D during development. Eur J Neurosci 19:2622-2632. CrossRef Medline

Worzfeld T, Rauch P, Karram K, Trotter J, Kuner R, Offermanns S (2009) Mice lacking Plexin-B3 display normal CNS morphology and behaviour. Mol Cell Neurosci 42:372-381. CrossRef Medline

Wu H, Fan J, Zhu L, Liu S, Wu Y, Zhao T, Wu Y, Ding X, Fan W, Fan M (2009) Sema4C expression in neural stem/progenitor cells and in adult neurogenesis induced by cerebral ischemia. J Mol Neurosci 39:27-39. CrossRef Medline

Wu W, Wong K, Chen J, Jiang Z, Dupuis S, Wu JY, Rao Y (1999) Directional guidance of neuronal migration in the olfactory system by the protein Slit. Nature 400:331-336. CrossRef Medline

Yukawa K, Tanaka T, Yoshida K, Takeuchi N, Ito T, Takamatsu H, Kikutani H, Kumanogoh A (2010a) Sema4A induces cell morphological changes through B-type plexin-mediated signaling. Int J Mol Med 25:225-230. CrossRef Medline

Yukawa K, Tanaka T, Kishino M, Yoshida K, Takeuchi N, Ito T, Takamatsu H, Kikutani H, Kumanogoh A (2010b) Deletion of Sema4D gene reduces intimal neovascularization and plaque growth in apolipoprotein E-deficient mice. Int J Mol Med 26:39-44. CrossRef Medline 